Report of Investigation 2017-10

\title{
GEOLOGIC MAP OF MOUNT CHIGINAGAK VOLCANO, ALASKA
}

Janet R. Schaefer, William E. Scott, and Paul W. Layer 
Cover. View to the northwest, up Bear valley, showing vent 5567 and associated lava flows and valley-filling block and ash flow. Photo by Willie Scott, August 24, 2008. AVO image database link: http://www.avo.alaska.edu/images/image. php?id=91651. 


\section{GEOLOGIC MAP OF MOUNT CHIGINAGAK VOLCANO, ALASKA}

Janet R. Schaefer, William E. Scott, and Paul W. Layer

Report of Investigation 2017-10

State of Alaska

Department of Natural Resources

Division of Geological \& Geophysical Surveys 


\section{STATE OF ALASKA}

Bill Walker, Governor

\section{DEPARTMENT OF NATURAL RESOURCES}

Andrew T. Mack, Commissioner

\section{DIVISION OF GEOLOGICAL \& GEOPHYSICAL SURVEYS}

Steve Masterman, State Geologist and Director

Publications produced by the Division of Geological \& Geophysical Surveys (DGGS) are available for free download from the DGGS website (dggs.alaska.gov). Publications on hard-copy or digital media can be examined or purchased in the Fairbanks office:

Alaska Division of Geological \& Geophysical Surveys 3354 College Rd., Fairbanks, Alaska 99709-3707

Phone: (907) 451-5010 Fax (907) 451-5050

dggspubs@alaska.gov|dggs.alaska.gov

DGGS publications are also available at:

Alaska State Library,

Historical Collections \& Talking Book Center

395 Whittier Street

Juneau, Alaska 99811

Alaska Resource Library and Information Services (ARLIS)

3150 C Street, Suite 100

Anchorage, Alaska 99503

\section{Suggested citation:}

Schaefer, J.R., Scott, W.E., and Layer, P.W., 2017, Geologic map of Mount Chiginagak volcano, Alaska: Alaska Division of Geological \& Geophysical Surveys Report of Investigation 2017-10, 31 p., 1 sheet, scale 1:25,000. http://doi.org/10.14509/29769
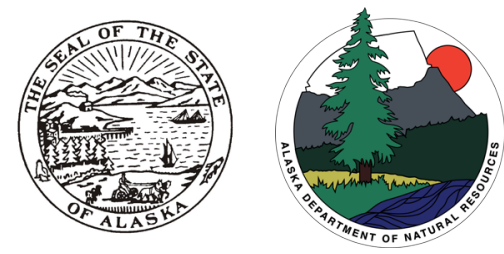



\section{Contents}

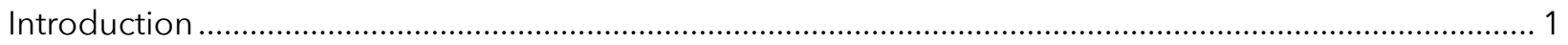

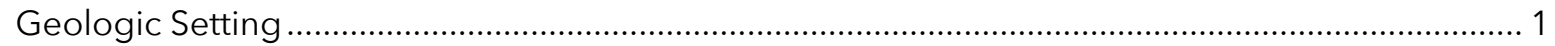

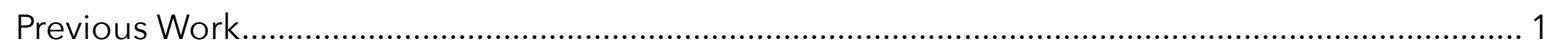

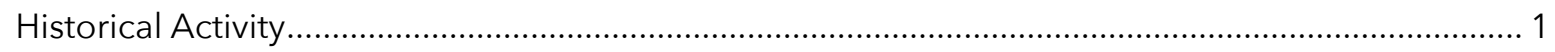

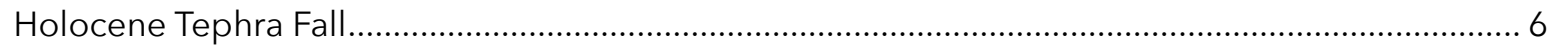

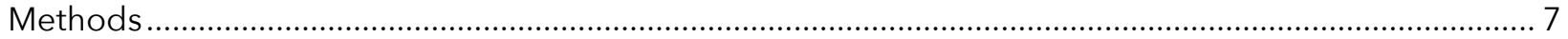

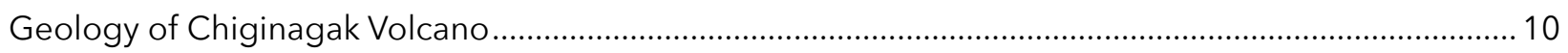

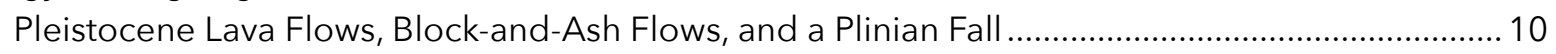

Holocene Lava Flows, Pyroclastic Flows, and Block-and-Ash Flows ........................................... 11

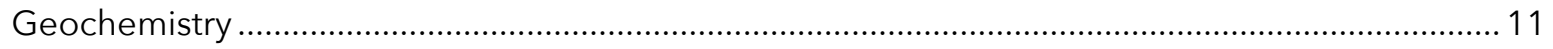

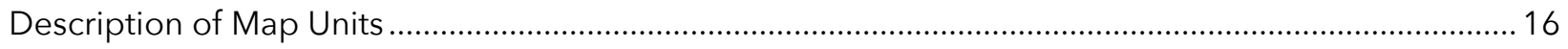

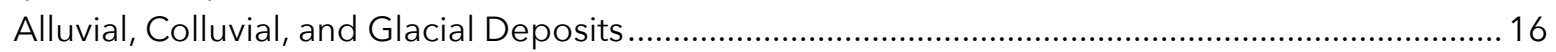

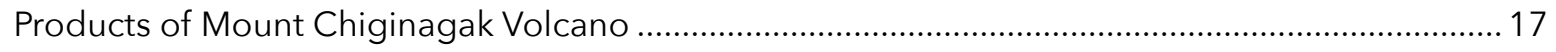

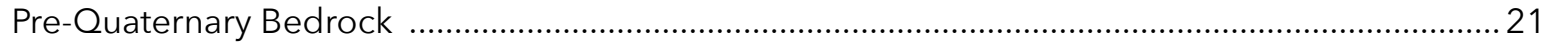

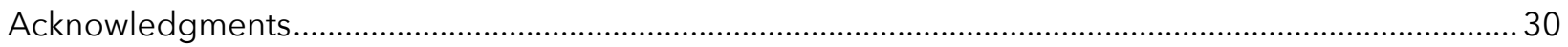

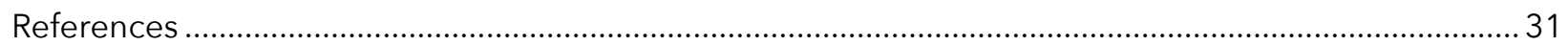

Figures

Figure 1. Location of Mount Chiginagak volcano and adjacent historically active volcanoes ................... 2

Figure 2. Tephra stratigraphic section 05JRSCH012 with 11 tephras preserved in the top

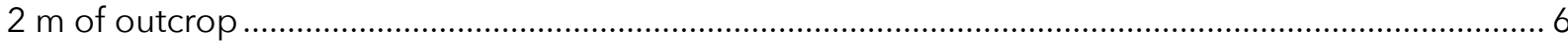

Figure 3. Northwest flank tephra station 05JRSCH019 with radiocarbon-dated soils ............................. 7

Figure 4. Weight percent $\mathrm{SiO}_{2}$ vs. weight percent $\left[\mathrm{Na}_{2} \mathrm{O}+\mathrm{K}_{2} \mathrm{O}\right]$, and weight percent $\mathrm{SiO}_{2}$ vs.

[FeO/MgO], showing the calc-alkaline grouping of Chiginagak lavas compared to

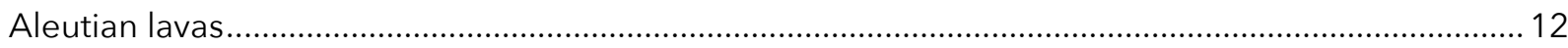

Figure 5. Weight percent $\mathrm{SiO}_{2}$ vs. weight percent $\left[\mathrm{Na}_{2} \mathrm{O}+\mathrm{K}_{2} \mathrm{O}\right]$ for Chiginagak lavas,

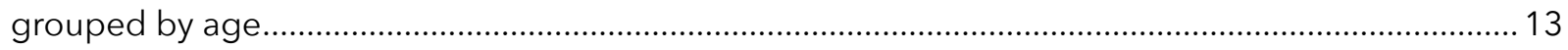

Figure 6. Harker diagrams for select major elements ........................................................................... 14

Figure7. Plot of $\mathrm{Sr}(\mathrm{ppm})$ vs. Ce (ppm) for Chiginagak Pleistocene lavas and plot of Sr (ppm)

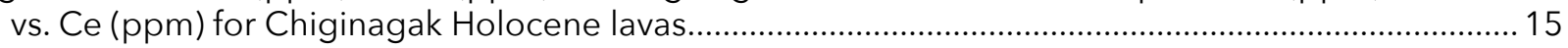

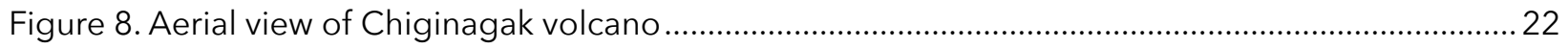

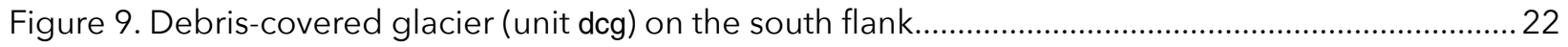

Figure 10. Glacial till of late Neoglacial age (upper Holocene) forming a sharp-crested mo-

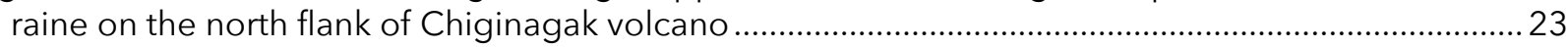

Figure 11. Debris-flow deposit preserved alongside the current drainage of upper Indeci-

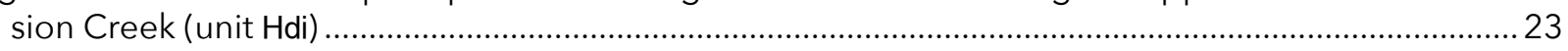

Figure 12. Holocene pyroclastic-flow and lahar deposits along Chiginagak Creek (unit Hdf).................2 24

Figure 13. Blocky andesite lava flow on the east flank of Chiginagak volcano (unit HIs).........................24

Figure 14. View to the northwest, up Bear valley, showing vent 5567 and associated lava flows............25

Figure 15. Geologist Janet Schaefer (DGGS/AVO) collects a sample from a prismatically

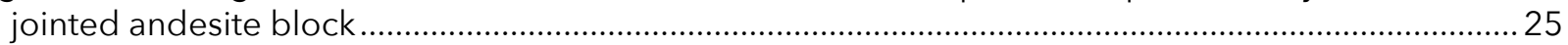

Figure 16. Andesite lava flow (unit Hpbv) exposed in a stream cut on the west side of the

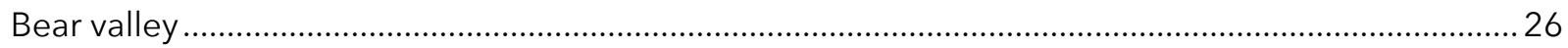

Figure 17. Hydrothermally altered lavas (units Pla and HPIb) in the summit region ...............................26

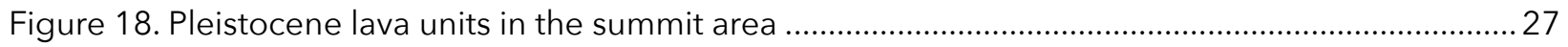


Figure 19. Holocene colluvium forms a sheet of talus at the base of Pleistocene ice-contact lava flows (unit PI) in upper Indecision Creek.

Figure 20. Banded andesite lava block from unit Pnb on the north flank ..............................................28

Figure 21. Basaltic andesite lava flows and a closer view of cliff-forming Plo lava flows .........................29

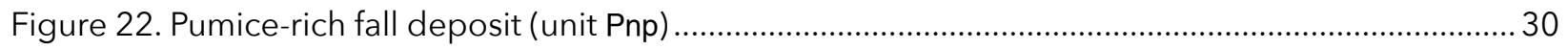

\section{Tables}

Table 1. Major-oxide XRF analyses of whole-rock samples and sediments rich in hydrother-

mally altered material from Chiginagak volcano ................................................................................. 3

Table 2. ${ }^{40} \mathrm{Ar} /{ }^{39} \mathrm{Ar}$ plateau ages (preferred age) for Chiginagak lavas....................................................... 8

Table 3. Radiocarbon ages of two organic-rich samples at site 09JRSCH019....................................... 10

\section{Appendices}

Appendix 1 (digital Excel spreadsheet in accompanying digital data distribution package). Whole-rock, major-oxide XRF, and trace-element XRF and ICP-MS analyses of whole-rock samples and sediments rich in hydrothermally altered material from Chiginagak volcano (normalized to $100 \%$ without volatiles; all Fe converted to FeOT; original analytical totals given in the "Total-majors" column). Major oxides are reported as weight percent oxide, and trace elements are reported in parts per million (ppm). Also included are samples taken by J. Riehle and E. Yount (published in the Alaska Geochemical Database [Granitto and others, 2013]). Riehle and Yount samples with bold, italicized location information are those for which we have determined that the location provided in Granitto and others (2013) is incorrect (see notes in Location Description field for these samples).

Appendix 2 (digital Excel spreadsheet in accompanying digital data distribution package). ${ }^{40} \mathrm{Ar} /{ }^{39} \mathrm{Ar}$ age dating information for Chiginagak lavas.

\section{Sheets}

Sheet 1: Geologic map of Mount Chiginagak volcano. 



\title{
GEOLOGIC MAP OF MOUNT CHIGINAGAK VOLCANO, ALASKA
}

\author{
Janet R. Schaefer ${ }^{1}$, William E. Scott ${ }^{2}$, and Paul W. Layer ${ }^{3}$
}

\section{INTRODUCTION \\ Geologic Setting}

Mount Chiginagak is a small $(-8 \mathrm{~km}$ diameter), hydrothermally active stratovolcano on the Alaska Peninsula about $300 \mathrm{~km}$ southwest of Anchorage, Alaska (fig. 1). The volcano is part of the 2,600-km-long Aleutian volcanic arc and lies approximately $290 \mathrm{~km}$ northwest of the subduction zone marked by the Aleutian trench. Adjacent volcanic centers are Yantarni Volcano, $18 \mathrm{~km}$ to the southwest, and Mount Kialagvik, $16 \mathrm{~km}$ to the northeast. This relatively close cluster of three volcanoes lies between two historically active volcanic centers-Aniakchak caldera, $75 \mathrm{~km}$ to the westsouthwest, and the Mount Ugashik-Mount Peulik volcanic center, $80 \mathrm{~km}$ to the northeast.

Chiginagak volcano is built on the southwestern end of a southwest-northeast-trending anticline, one in a series of broad folds in the Naknek Formation along the Alaska Peninsula. Bedrock surrounding the volcano consists predominantly of Upper Jurassic Naknek Formation sandstone and siltstone as well as intrusive rocks of Miocene and Pliocene age (Detterman and others, 1987a).

\section{Previous Work}

Detterman and others (1987a, 1987b; reproduced in Miller and others, 1998) published 1:250,000-scale geologic maps of both the bedrock and Quaternary deposits surrounding Chiginagak volcano. Their map scale only allowed for a generalized grouping of volcanic units at Chiginagak and no samples were collected for geochemical analysis (Detterman, 1987b). Riehle (1990; written commun., 2000) presented a significantly different generalized map, but like the Detterman maps, only represented very generalized units consisting of primarily lava flows and domes, older pyroclastic flows low on the northwest flank, and the youngest products described as an unglaciated lava flow and overlying block-and-ash flow extending east into the valley on the southeast flank. Eighteen samples of Chiginagak lavas are recorded in the Alaska Geochemical Database (Granitto and others, 2013; sample collectors J. Riehle or B. Yount) and are included in this report along with geochemical results reported for this study (table 1 ; appendix 1 [in accompanying digital data distribution package]).

\section{Historical Activity}

Historical reports of activity (within the last -230 years) at Chiginagak are limited and typically consist of descriptions of "steaming" and "smoking" (Coats, 1950; Powers, 1958). A fumarole field at an elevation of $-1,740$ to $1,800 \mathrm{~m}$ on the north flank has been emitting gas throughout historical time and occasionally appears to increase in vigor, prompting reports from area residents. In 1971, a small ash eruption was reported by a resident of Port Heiden, $-100 \mathrm{~km}$ southwest of the volcano, but never confirmed (Miller and others, 1998). In October 1997, residents in Pilot Point ( -60 $\mathrm{km}$ northwest of the volcano) reported increased steaming and snowmelt near the north flank fumarole field (McGimsey and Wallace, 1999). During a flight around the volcano on October 30, 1997, AVO scientists observed an enlarged area of fumarolic activity on the north flank and reported a very strong sulfur smell (McGimsey and Wallace, 1999). Similar reports have been received over the

\footnotetext{
${ }^{1}$ Alaska Division of Geological \& Geophysical Surveys, 3354 College Rd., Fairbanks, Alaska 99709-3707

2 David A. Johnston Cascades Volcano Observatory, U.S. Geological Survey, 1300 SE Cardinal Court, Suite 100, Vancouver, Washington 98683

${ }^{3}$ College of Natural Science and Mathematics, University of Alaska Fairbanks, 900 Yukon Drive, Fairbanks, AK 99775
} 


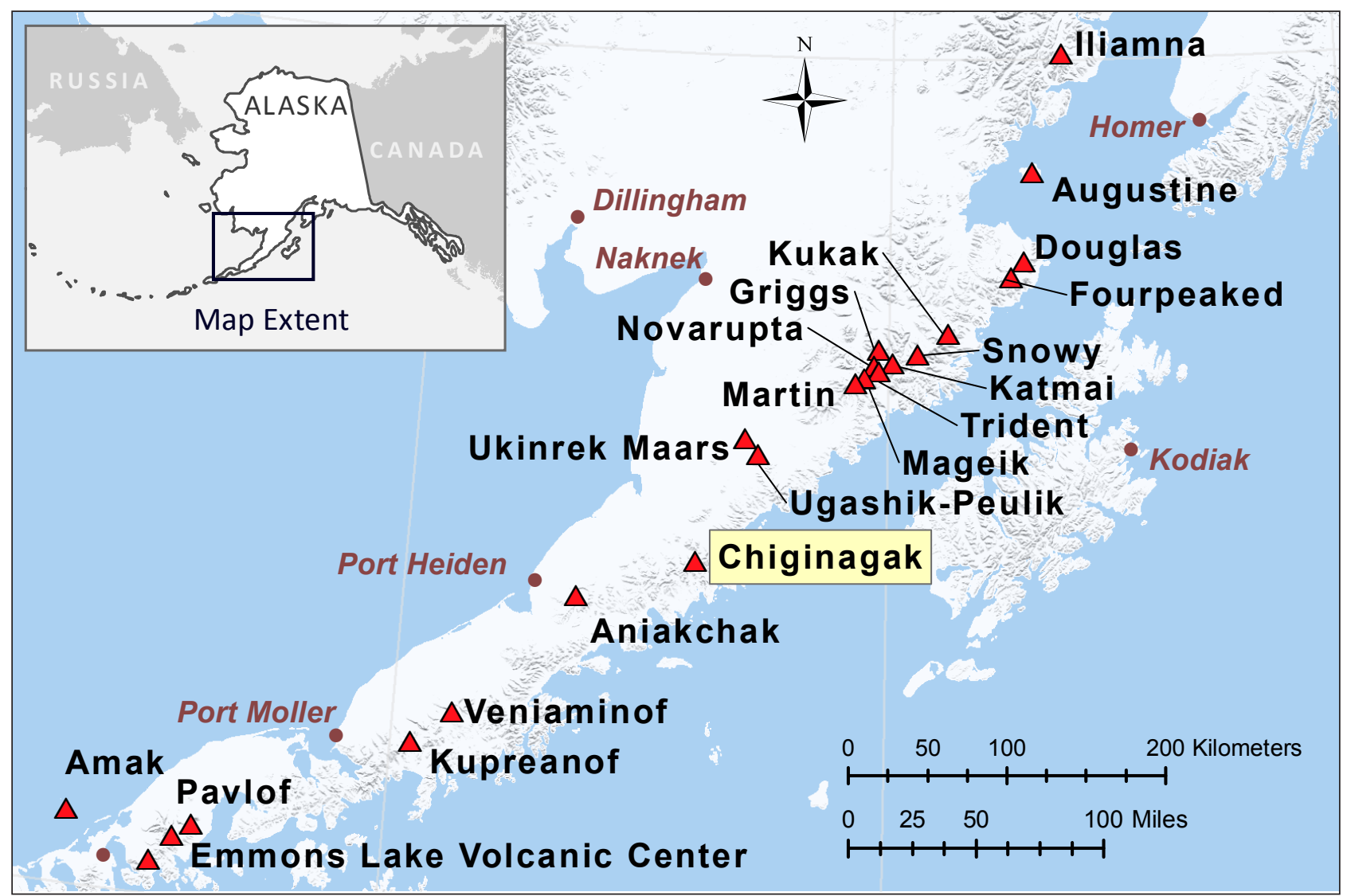

Figure 1. Location of Mount Chiginagak volcano and adjacent historically active volcanoes on the Alaska Peninsula.

last several years (2005-2012) from a resident at Lower Ugashik Lake $(-50 \mathrm{~km}$ north of the volcano) who occasionally reports apparent increases in steaming and snowmelt around the fumarole field.

Observations of the volcano in 1998 described by McGimsey and others (2003) are summarized here. On August 13, 1998, U.S. Fish and Wildlife Service (USFWS) personnel and a resident of Pilot Point $(60 \mathrm{~km}$ northwest of Chiginagak) observed little clouds of "black smoke" accompanied by a "greenish-yellow" gas rising from two point sources to an elevation of approximately 150-300 m above the summit. On August 15 , a $30-\mathrm{km}$-long gas plume was detected in satellite imagery. An airborne ultraviolet correlation spectrometer (COSPEC) flight to Chiginagak on September 29, 1998, measured a $\mathrm{SO}_{2}$ efflux of 200-300 metric tons per day from the north flank fumarole field. No indication of gas release or unusual heating (ice melt) was observed at the summit region during the observational flights conducted in 1997 and 1998.

No other unusual activity was reported at the volcano until July 2005, when the Alaska Volcano Observatory (AVO) was contacted by a local lodge owner who described orange foamy water pouring into Mother Goose Lake from Volcano Creek, a strong smell of sulfur, and the absence of fish in Mother Goose Lake, King Salmon River, and Painter Creek (J. Kent, oral commun., 2005). In early August 2005, reports from local USFWS staff indicated a vast area of vegetation damage along Volcano Creek and Indecision Creek, which drain the flanks and summit region of Chiginagak volcano (S. Savage, oral commun., 2005). On August 20, 2005, a site visit by AVO staff (J. Schaefer, W. Scott, and G. McGimsey) confirmed the presence of a 300-m-wide lake in what six months earlier 
穼焉

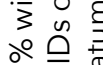

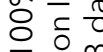

유

인전

Nㅡ엥

है

ह $\frac{1}{0}$

$\subseteq \stackrel{\simeq}{\subseteq}$

으을

은 을

은 ज

등

O응

宅远

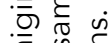

U 0.0

ह $\frac{\sigma}{\pi}$

은 w

.

$\frac{\pi}{\frac{\pi}{\sigma}} \frac{\lambda}{0}$

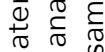

$\varepsilon \sim$

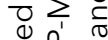

过造

$\frac{\Phi}{\sigma} \bar{\partial}$

름

है 눟

$\frac{1}{0} \times$

步

응

등

$\subseteq 0$

는

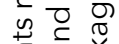

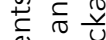

ย嵅

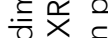

(⿻)

믈 즘

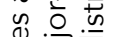

을

है

它 v

는

ㄴํㅇ

i 0

읻

उ宊

प०

ฆ ए ह

n 0 엉

तิ

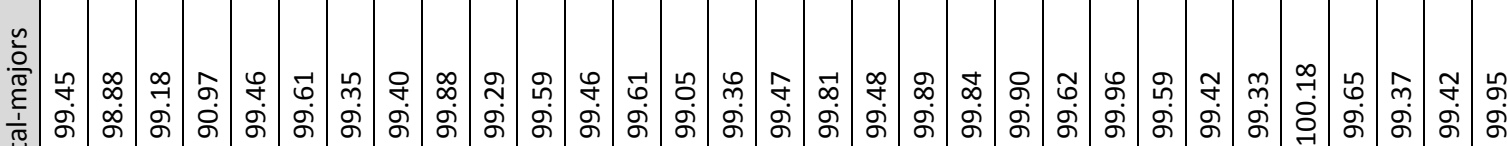
응

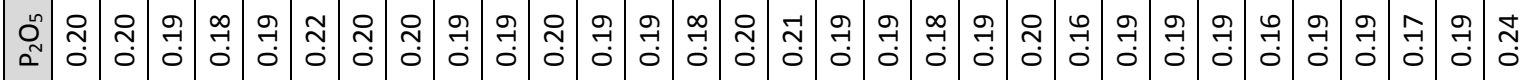

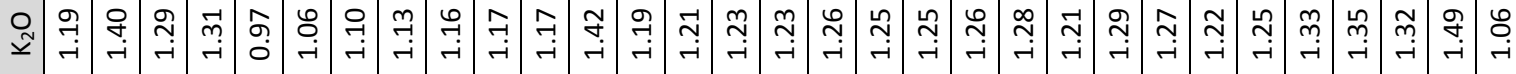

유

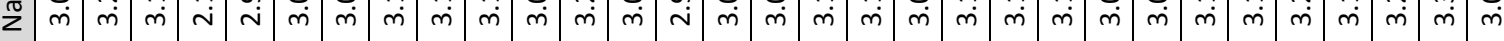

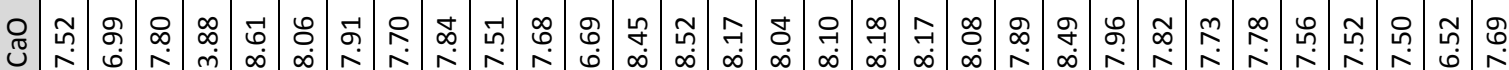

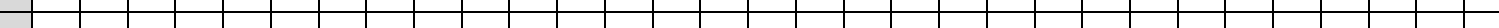

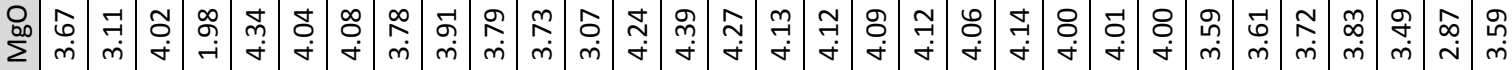

일

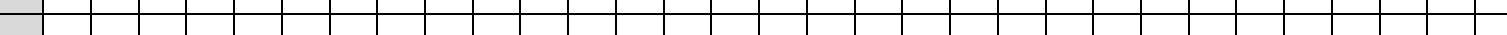

䤉

О ఫ 若

으 잉 in 过 穴

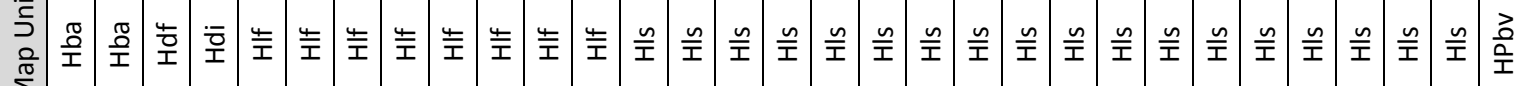

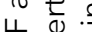

$\frac{\pi}{x} \geq \frac{\sigma}{x}$

0)

.

이용

을 的

$\sum \frac{0}{\pi}=$

- $\frac{0}{0}$

$\frac{\pi}{0} \stackrel{0}{2}$

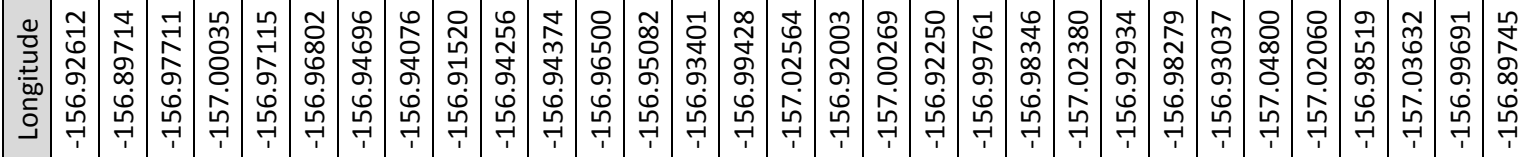

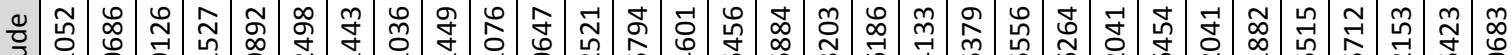
王

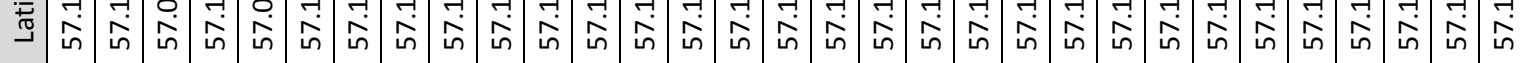

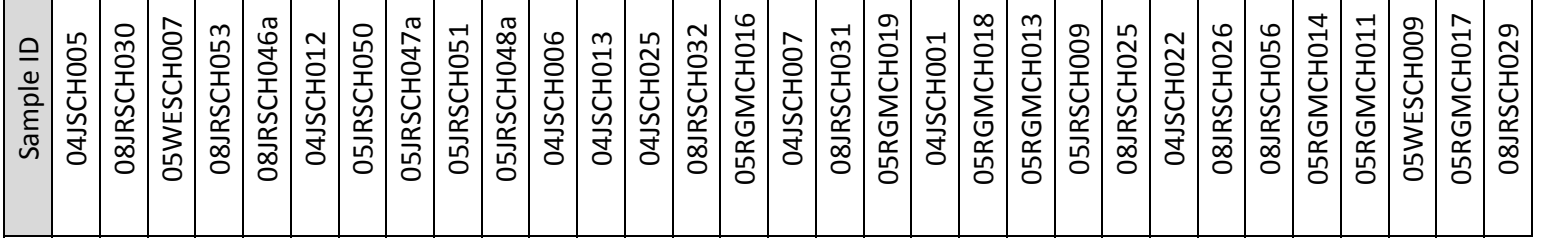




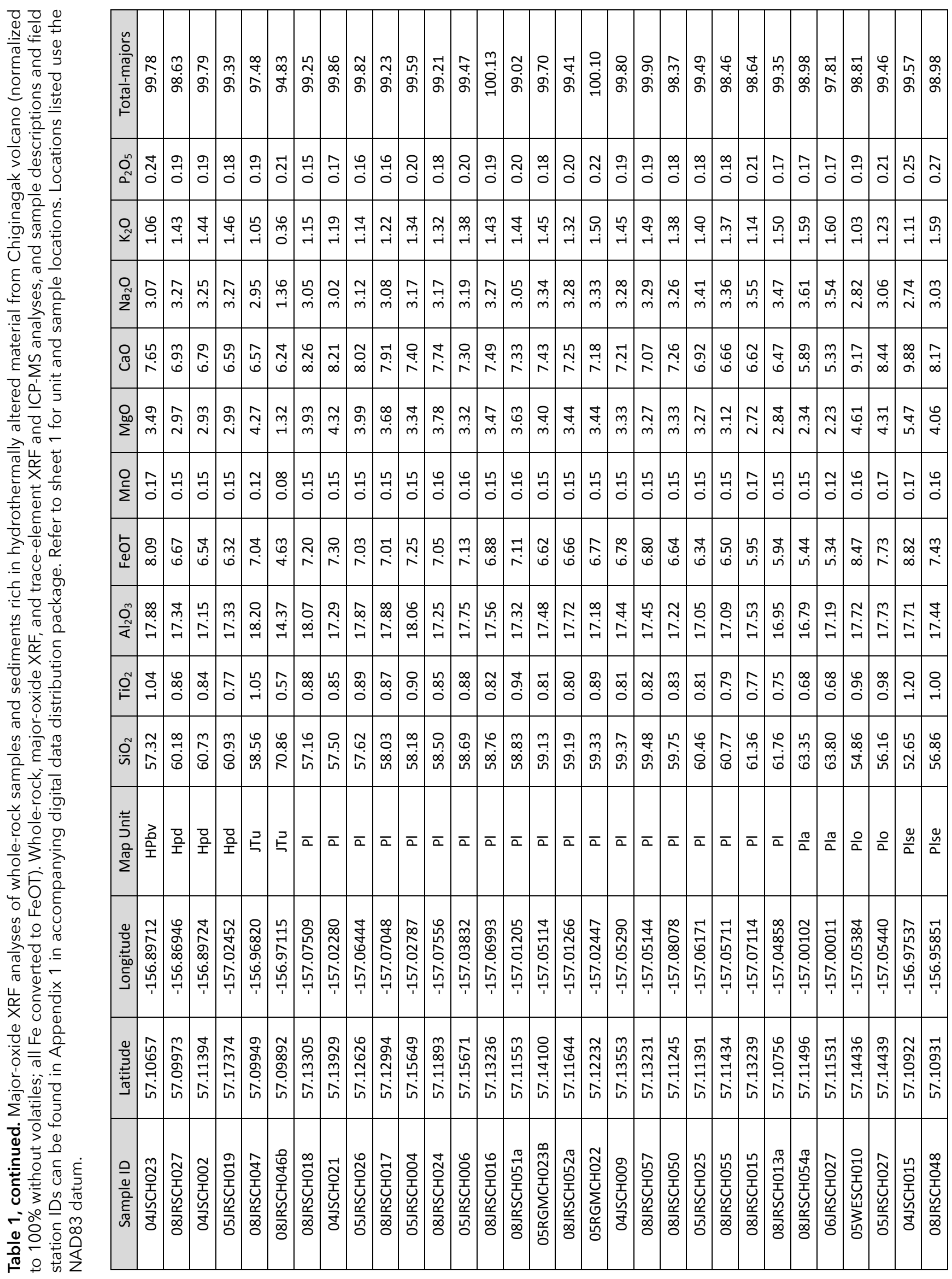




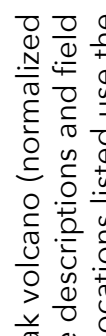

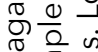

$\subseteq \frac{\varepsilon}{0}$

흔

U⿺辶寸

$\varepsilon \frac{\pi}{0}$

它

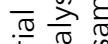

$\Phi$

$\stackrel{\infty}{\xi} \sum_{i}^{n} \frac{c}{\pi}$

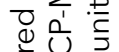

我

$\frac{ \pm}{\sigma} \overline{0} \stackrel{0}{0}$

颃完

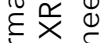

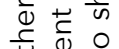

to

产这

空过

$\subseteq \cup$

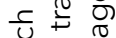

든

인

峁

릉

过.

응

ते $\frac{1}{0}$

电 $\frac{\pi}{\pi} \frac{\pi}{\pi}$

응

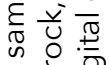

눙

응

过

官官

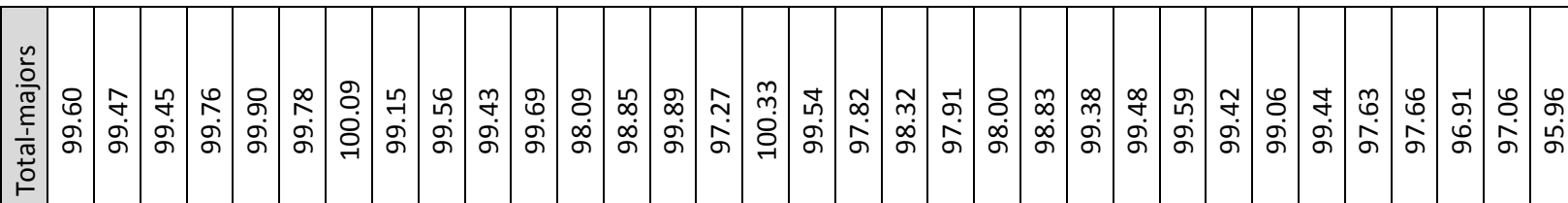

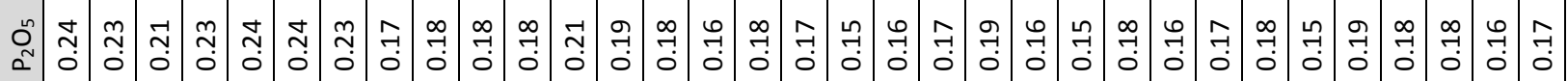

O)

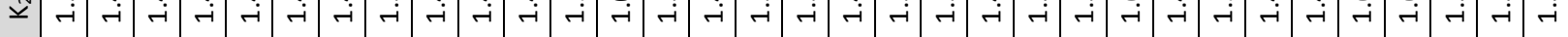

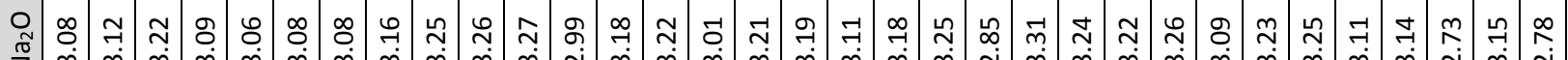

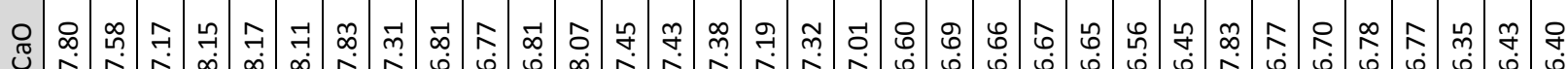

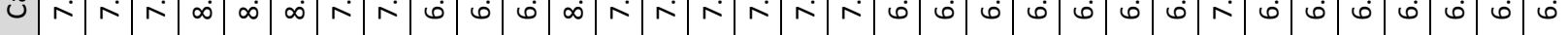

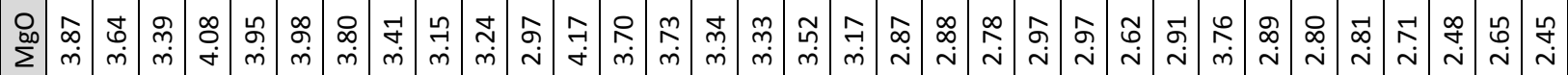

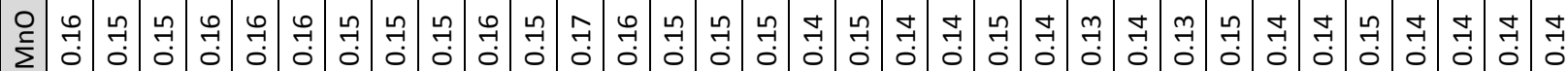

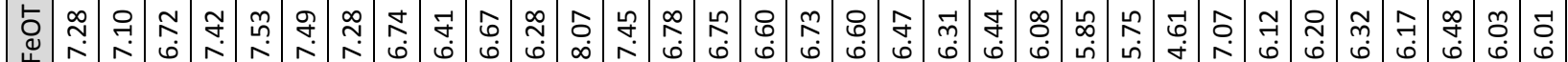

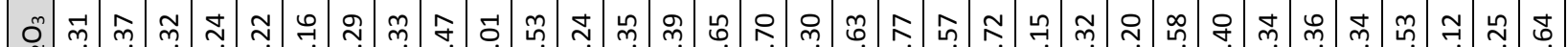

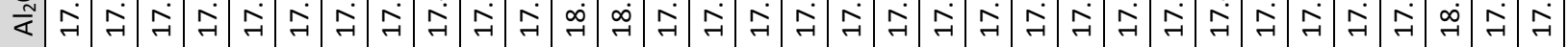

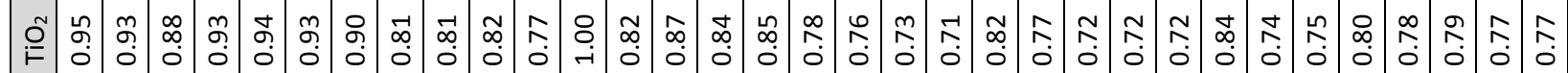

๙

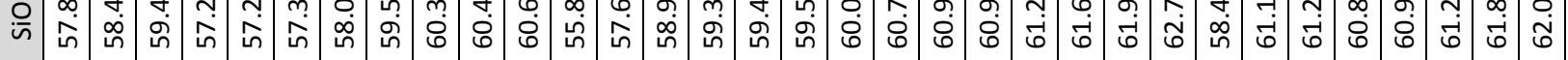

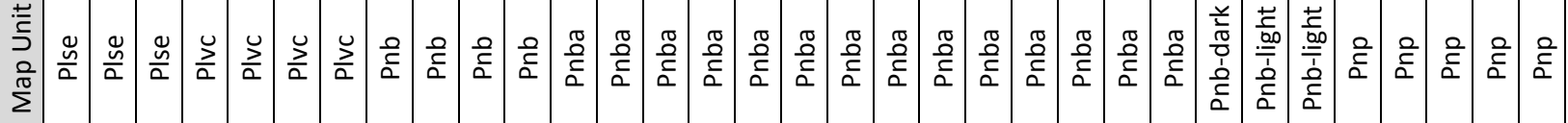

范

0

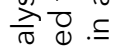

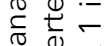

崩 $\geq$

×

은 늉

霅 $\overline{\bar{\sigma}}$

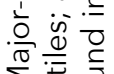

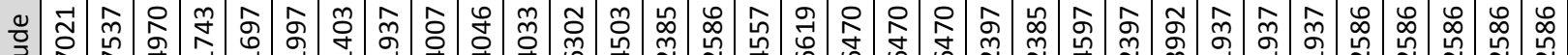

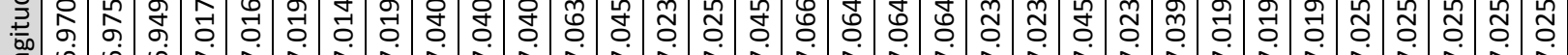

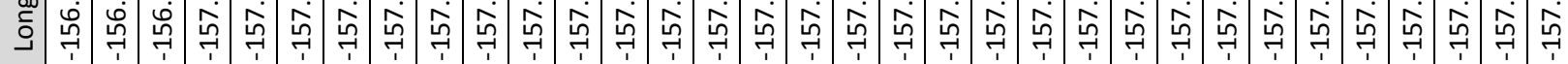

$\sum \underset{\pi}{0}$

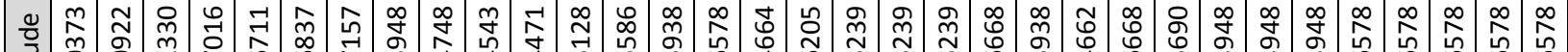

封

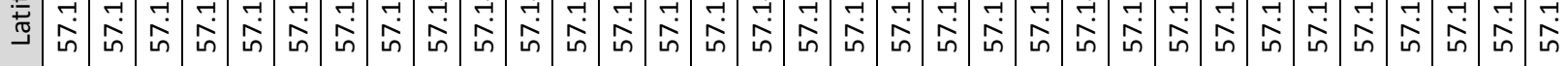

ชั

.

ปั่

ᄃ

๘

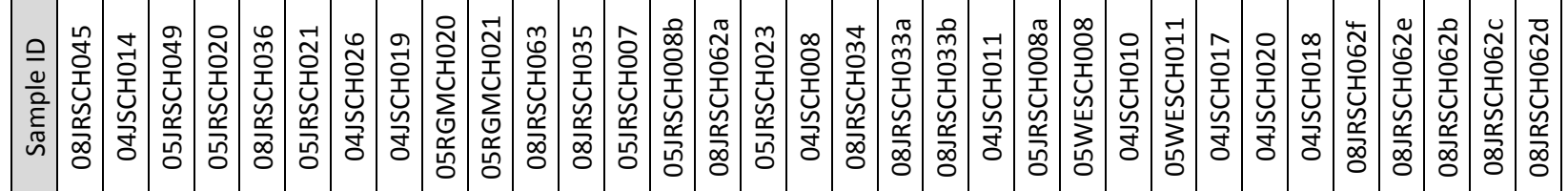


had been a snow- and ice-filled summit crater. A detailed report on the noneruptive heating event and subsequent ice melt, lahar, acid flood, and sulfuric-acid-aerosol release is presented in Schaefer and others (2008).

\section{Holocene Tephra Fall}

Distal tephra samples with Chiginagak volcano as the known source are rare. Riehle and others (1999) identified, at three sites, four tephras that he inferred to have originated from Chiginagak, on the sole basis of proximity to the volcano (two sites are within $12 \mathrm{~km}$ of the central vent and one distal site is $-55 \mathrm{~km}$ to the northeast). During geologic mapping for this study, tephras were collected at 21 sites in the map area. In addition, as part of a study of past acidic floods from Chig- inagak's summit crater, lake cores were extracted from Mother Goose Lake in 2006 and 2007 (Kassel, 2009); these cores contain up to 52 tephras spanning 3,400 years, presumably from Chiginagak and other Alaska Peninsula volcanoes. A thorough tephrochronologic study is in progress and will include glass geochemistry, componentry, eruption volume, and frequency estimates. Our preliminary observations indicate that explosive, tephra-producing eruptions greater than VEI 3 have been infrequent at Chiginagak volcano. Of the proximal tephra sites investigated (within $\sim 8$ $\mathrm{km}$ of the summit vent), there are generally fewer than four, less-than-4-cm-thick tephras in the upper several meters of section, although one site on the northwest flank (Station 05JRSCH012, fig. 2) has 11 tephras preserved in the upper $2 \mathrm{~m}$

Figure 2. Tephra stratigraphic section 05JRSCH012 with 11 tephras preserved in the top 2 $\mathrm{m}$ of outcrop. Inset photomicrograph of tephra 05JRSCH012h shows $>250 \mu \mathrm{m}$ fraction containing frothy to fibrous, blocky to elongate, yellow pumice clasts.

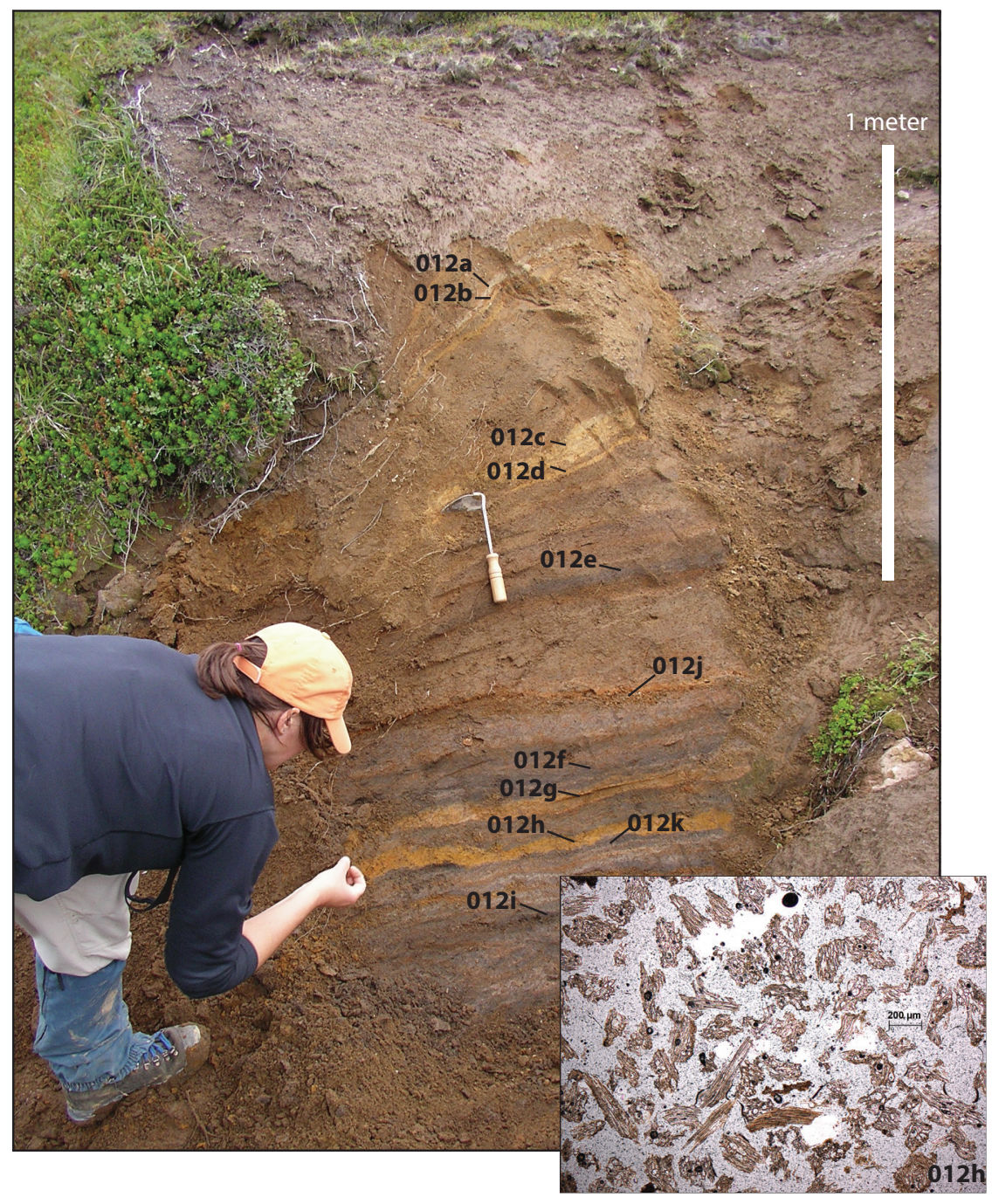


of outcrop. Station 05JRSCH019, on the northwest flank, with $4 \mathrm{~m}$ of exposure, contains three tephras; the oldest tephra exposed, at a depth of $1.2 \mathrm{~m}$ in section, is directly overlain by a soil with an age of $3,170 \pm 90{ }^{14} \mathrm{C}$ yBP (fig. 3). Proximal late Holocene Chiginagak tephras have variable componentry, but all contain at least 15 percent frothy orange-yellow pumice clasts that are often elongate and fibrous (fig. 2).

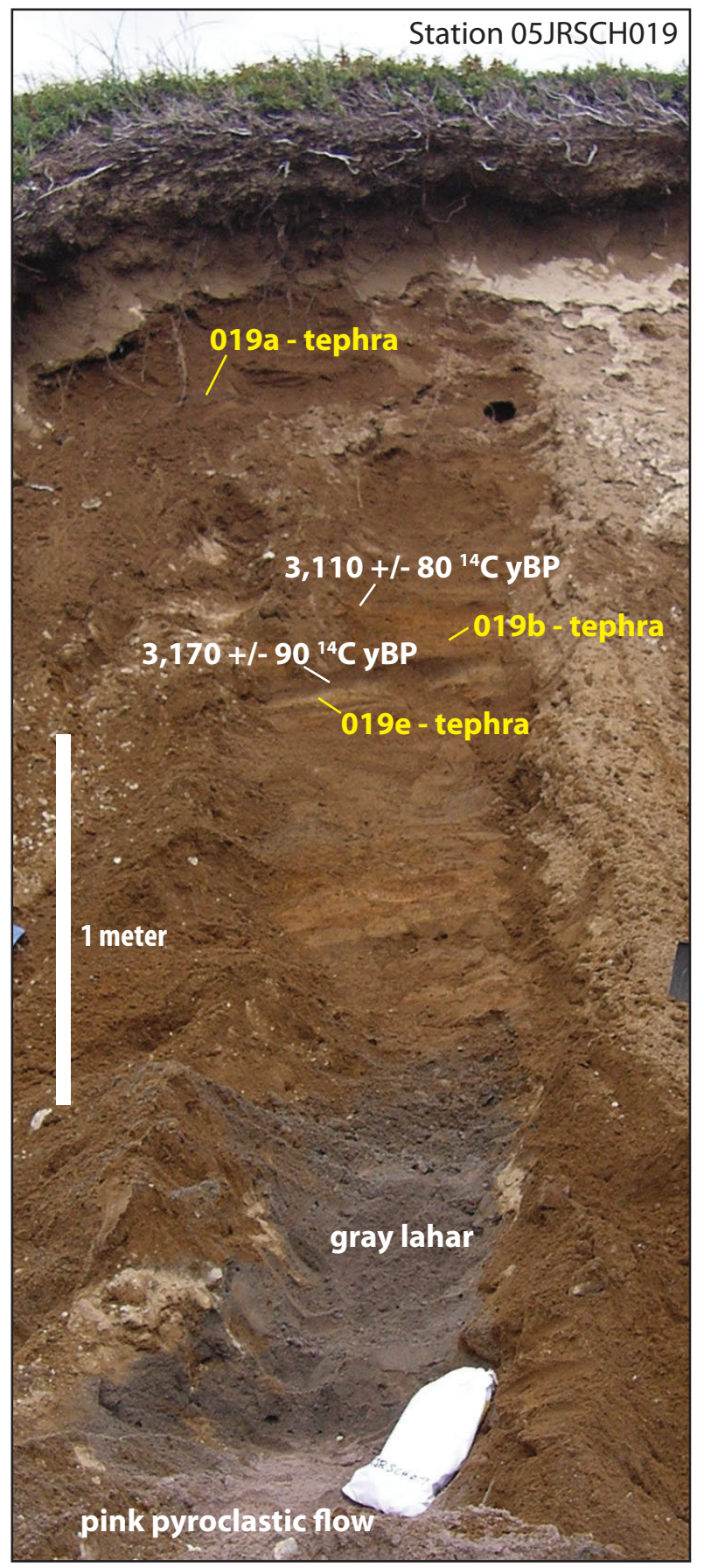

\section{METHODS}

Geologic field mapping, rock sampling, and tephra stratigraphy were conducted at Chiginagak volcano during short field excursions (2-6 days each) in 2004, 2005, 2006, 2008, and 2011. Orthorectified black-and-white airphotos from 1953, and satellite imagery such as Quickbird, Worldview, and Landsat7 aided geologic contact mapping. In particular, the $-1-\mathrm{m}$-pixel Worldview image acquired August 8, 2008, served as the most useful basemap for post-fieldwork geographical information system (GIS) mapping.

${ }^{40} \mathrm{Ar} /{ }^{39} \mathrm{Ar}$ age dating of lavas was conducted at the University of Alaska Fairbanks geochronology lab following procedures outlined in Layer (2000) and Macías and others (2010). For all samples, we report the plateau age as the preferred age (table 2; appendix 2 [in accompanying digital data distribution package]). For this study, two laser heating runs were conducted for each crushed whole-rock sample. The first run was completed on a small number of grains to gauge the correct amount of material to use as well as to determine an optimal heating schedule for the second run. The second runs contained more material and generally produced more precise ages. Isochron ages are similar to plateau ages; however, atmospheric initial ratios are less precise, thus plateau age is reported. Only those samples with 1-sigma precisions less than 18 ka are considered useable and reported in table 1; however, an age of $171 \pm 63 \mathrm{ka}$ is included because it provides an approximate age of a relatively old deposit.

Rock samples were analyzed for major and trace-element composition by the Washington State University (WSU) GeoAnalytical Laboratory (table 1). Major oxides are reported as weight percent oxide, and trace elements are reported in parts per million (ppm). Hand samples and clean, minimally weathered rock chips were collected on

Figure 3. Northwest flank tephra station

05JRSCH019 with radiocarbon-dated soils. Tephra and soils overlie Holocene pyroclastic flow and lahar deposits of unit Hpd. 


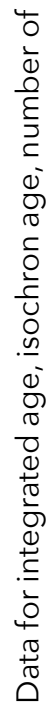

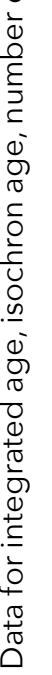

\begin{tabular}{|c|c|c|c|c|c|c|c|c|c|c|c|c|c|c|c|}
\hline 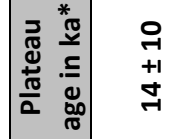 & $\stackrel{+}{+}$ & $\begin{array}{l}\infty \\
+1 \\
+\end{array}$ & $\begin{array}{l}\infty \\
+1 \\
\text { 足 } \\
n\end{array}$ & $\begin{array}{l}\sigma \\
+1 \\
\infty \\
\infty\end{array}$ & $\begin{array}{l}0 \\
\rightarrow \\
+1 \\
\varphi\end{array}$ & $\begin{array}{l}m \\
+1 \\
+1 \\
\text { +1 }\end{array}$ & 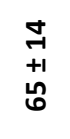 & $\begin{array}{l}\infty \\
+1 \\
+1 \\
0\end{array}$ & $\begin{array}{l}7 \\
+1 \\
\text { 吾 }\end{array}$ & $\begin{array}{l}\underset{7}{+} \\
+1\end{array}$ & $\stackrel{a}{\stackrel{+}{N}}$ & $\begin{array}{l}m \\
+1 \\
n\end{array}$ & $\begin{array}{l}\stackrel{\rho}{+1} \\
\stackrel{\alpha}{+}\end{array}$ & $\begin{array}{l}0 \\
+1 \\
0\end{array}$ & $\begin{array}{l}0 \\
+1 \\
\infty\end{array}$ \\
\hline \begin{tabular}{l}
$\infty$ \\
\multirow{0}{0}{} \\
in \\
?.
\end{tabular} & 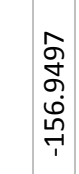 & $\begin{array}{l}\hat{n} \\
\hat{n} \\
\hat{o} \\
\stackrel{h}{1}\end{array}$ & 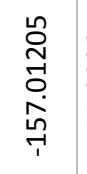 & 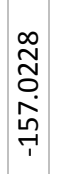 & 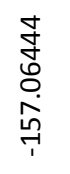 & 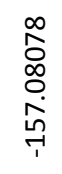 & 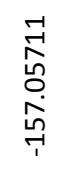 & 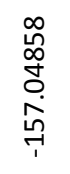 & $\begin{array}{l}\text { o. } \\
0 \\
0 \\
i \\
\text { in }\end{array}$ & $\begin{array}{l}\text { o. } \\
\text { م. } \\
\text { in } \\
\text { in }\end{array}$ & 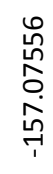 & 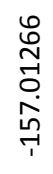 & 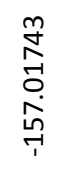 & 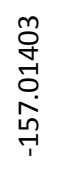 & 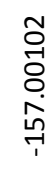 \\
\hline $\begin{array}{l}0 \\
\infty \\
\stackrel{7}{7} \\
i n\end{array}$ & $\begin{array}{l}\overrightarrow{0} \\
0 \\
\stackrel{9}{7} \\
i \\
i n\end{array}$ & $\begin{array}{l}\text { ते } \\
\text { ò } \\
\stackrel{i}{i} \\
\text { in }\end{array}$ & 总 & 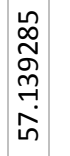 & 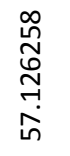 & & 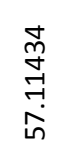 & 惫 & 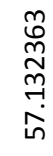 & $\begin{array}{l}\stackrel{n}{0} \\
\stackrel{0}{\rightarrow} \\
\stackrel{i}{n}\end{array}$ & $\begin{array}{l}\infty \\
\infty \\
\stackrel{+}{7} \\
i\end{array}$ & $\begin{array}{l}\text { 竎 } \\
\text { ?. } \\
\text { in }\end{array}$ & 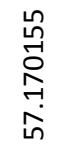 & 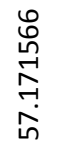 & $\begin{array}{l}\stackrel{8}{9} \\
\stackrel{+}{7} \\
\text { in }\end{array}$ \\
\hline
\end{tabular}

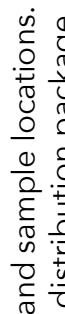

索量

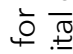

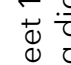

要.

है

व

家

그.

离.

券

บิ

혼

离.

일

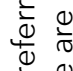

产

每

$\stackrel{\pi}{3}$

$\underset{\pi}{\mathbb{0}}$

원

远远

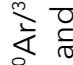

ก่

$\frac{0}{\frac{0}{0}} \cdot \frac{0}{4}$

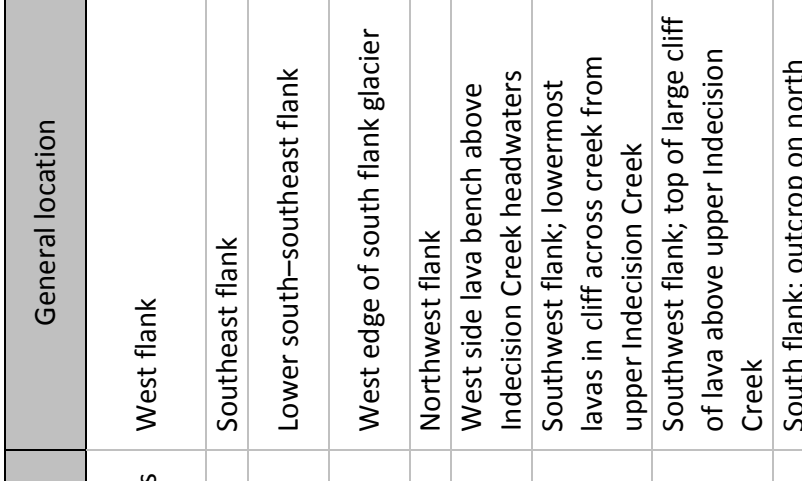

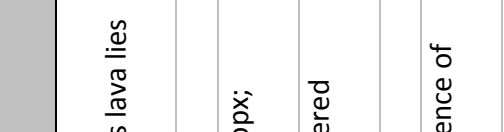

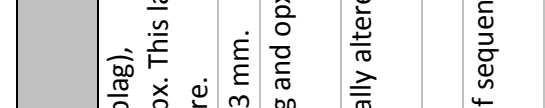

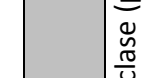

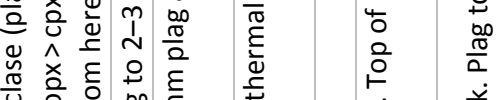

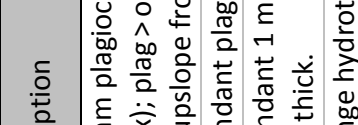

䇏离

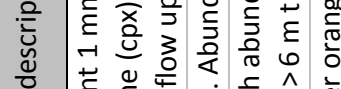

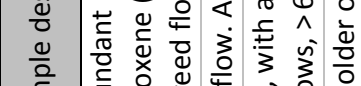

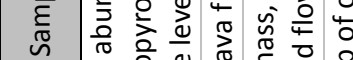

它它

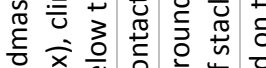

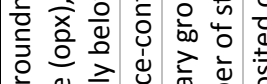

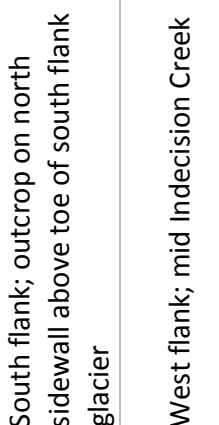

产

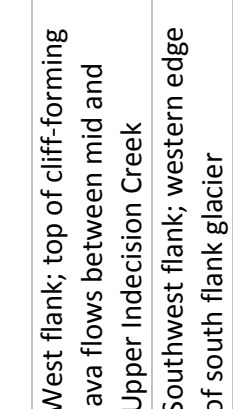

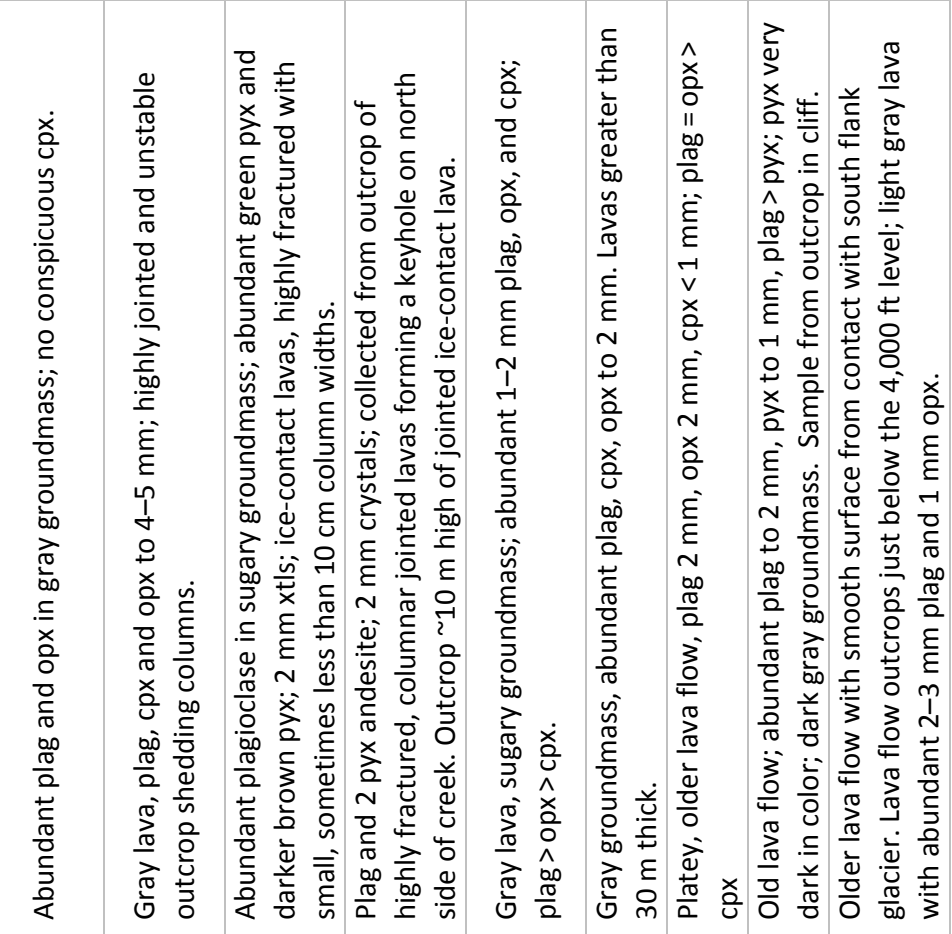

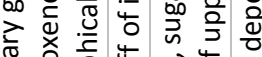

do

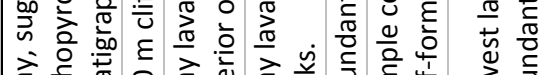

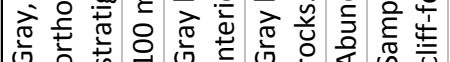

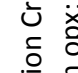

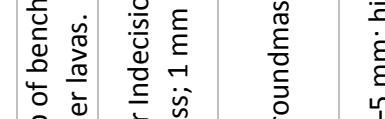

응 흥 है

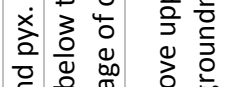

$\frac{\pi}{\sqrt{0}}$

誉

$\stackrel{.}{x}$

증

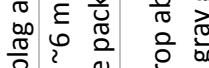

항

范

要

-

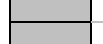

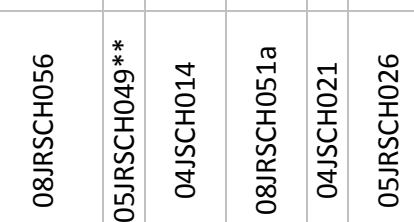

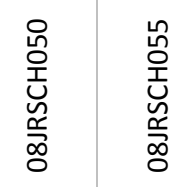

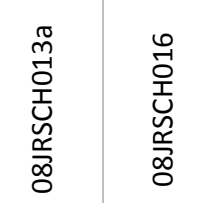

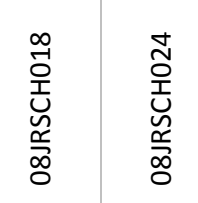

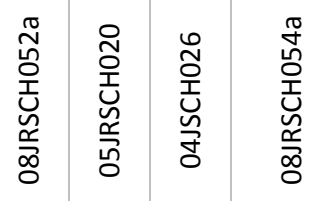

$\stackrel{\frac{0}{10}}{\frac{\pi}{2}} \frac{\sqrt[n]{5}}{5}$

포

$\bar{a} \bar{a} \bar{a}$

$\bar{a} \quad \bar{c}$

$\bar{a}$

$\bar{a} \quad \bar{\alpha}$

$\bar{\alpha} \quad \bar{\alpha}$

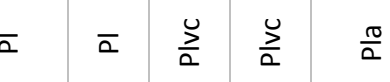




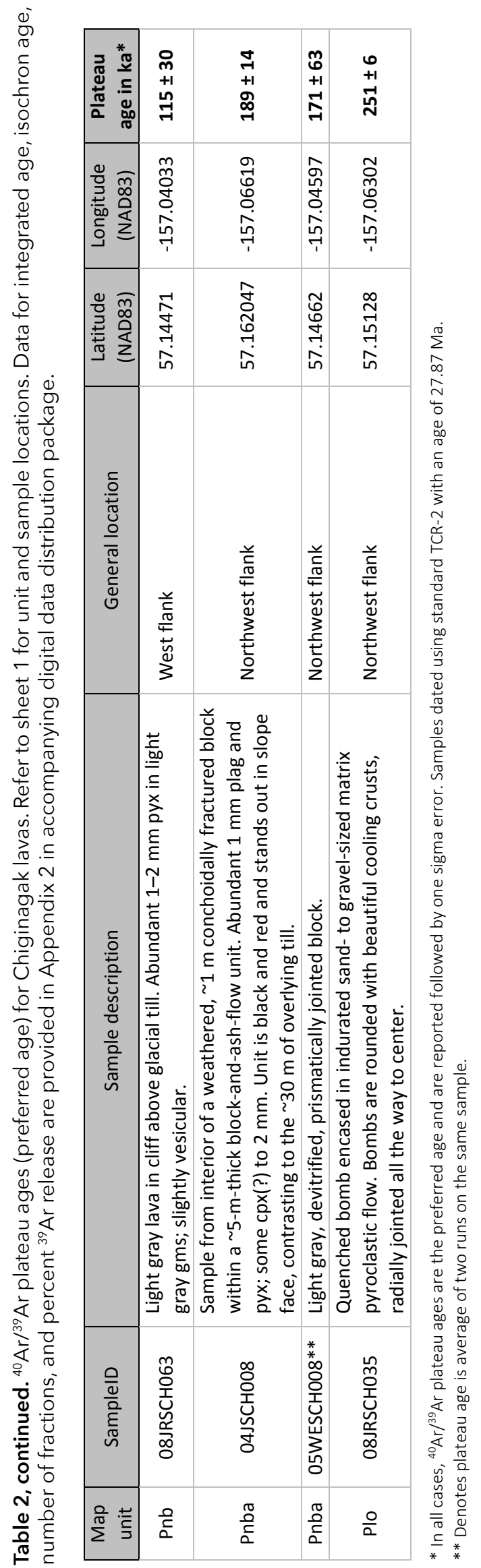


the outcrop. X-ray fluorescence (XRF) analyses were conducted following the methods outlined in Johnson and others (1999). Inductively coupled plasma mass spectrometry (ICP-MS) analyses for trace elements were conducted following the procedures described in Knaack and others (1994).

Two soil samples were submitted for conventional radiocarbon age dating at Geochron Laboratories, Cambridge, Massachusetts (table 3). Soil samples were dispersed in a large volume of water; clays and organic matter were isolated by agitation and ultrasound. The fine clay/organic fraction was passed through a fine nylon mesh to filter out rootlets. The clay/organic fraction was treated with dilute $\mathrm{HCl}$ to destroy carbonates. After filtering and washing, the clay/organic fraction was digested in $0.1 \mathrm{~N} \mathrm{NaOH}$ to solubilize humic acids. The supernatant humic acid solution was acidified to precipitate humates. The humate precipitate was filtered, dried, and combusted in oxygen to produce carbon dioxide for the analysis.

\section{GEOLOGY OF CHIGINAGAK VOLCANO}

The eruptive products of Chiginagak volcano record a history of chiefly andesite lava flows and associated block-and-ash flows. The oldest lavas exposed are Pleistocene in age and are found everywhere around the edifice except in the northeast sector, where Holocene lava flows dominate the landscape. Holocene activity has covered the northeast flank with rubbly-topped andesite lava flows that extend as far as $4.6 \mathrm{~km}$ from their source vent at the summit crater. The farthest-reaching volcanic deposits are on the southeast flank, where block-and-ash-flow, pyroclastic-flow, and lahar deposits extend down valley as far as $9 \mathrm{~km}$ from the summit. Limited exposure of deposits of a presumed plinian eruption of middle Pleistocene age indicate at least one episode of explosive activity in Chiginagak's past. A brief description of major units is summarized here, and a detailed description of all map units is found in the Description of Map Units below.

\section{Pleistocene Lava Flows, Block-and- Ash Flows, and a Plinian Fall}

The oldest lavas exposed at Chiginagak volcano are in cliff-forming block-and-ash and pyroclastic-flow deposits, related fluvial deposits, and minor lava flows on the northwest flank above Indecision Creek (units Plo and Pnba). A quenched lava bomb in a pyroclastic unit related to unit Plo is dated at $251 \pm 6 \mathrm{ka}$ (table 2). Two juvenile blocks stratigraphically higher in unit Pnba are dated at $189 \pm 14 \mathrm{ka}$ and $171 \pm 63 \mathrm{ka}$. The oldest lava flow exposed is a basaltic andesite of unit Plo (54.9 to 56.2 weight $\% \mathrm{SiO}_{2}$; table 1) interfingered with unit Pnba.

A several-meter-thick pumice-fall and related pumiceous deposits (unit Pnp) conformably underlie block-and-ash-flow deposits of unit Pnba. This Pleistocene fall deposit is evidence of the only major explosive eruption recognized in the geologic record at Chiginagak volcano. The exposure is limited and composed chiefly of pumiceous lapilli

Table 3. Radiocarbon ages of two organic-rich samples at site $09 \mathrm{JRSCH} 019 ; 57.1745^{\circ} \mathrm{N}, 157.0224^{\circ} \mathrm{W}$.

\begin{tabular}{|c|c|c|l|}
\hline Sample ID & Age & Calibrated Age (cal yBP)* & \multicolumn{1}{|c|}{ Sample Description } \\
\hline 05JRSCH019c & $\begin{array}{c}3,110+/-80 \\
{ }^{14} \mathrm{C} \text { years BP } \\
\left({ }^{13} \mathrm{C}\right. \\
\text { corrected) }\end{array}$ & $3536-3076$ cal yBP & $\begin{array}{l}\text { dark orange-brown organic layer } \\
\text { overlying tephra 05JRSCH019b; } \\
\text { approximately 1 m below the surface }\end{array}$ \\
\hline 05JRSCH019d & $\begin{array}{c}3,170+/-90 \\
{ }^{14} \mathrm{C} \text { years BP } \\
\left({ }^{13} \mathrm{C}\right. \\
\text { corrected) }\end{array}$ & $3600-3164$ cal yBP & $\begin{array}{l}\text { mixed dark gray-black and brown } \\
\text { organics and silty sands; directly } \\
\text { below tephra 05JRSCH019b, } \\
\text { approximately 1.1 m below the } \\
\text { surface }\end{array}$ \\
\hline
\end{tabular}

*OxCal v4.2.4 (Bronk Ramsey, 2009), IntCal13 atmospheric curve (Reimer and others, 2013). 
and ash, with less abundant small bombs, dense gray clasts, and accidental fragments. Pumiceous deposits of pyroclastic flows, lahars, and fluvial deposits enclose the main fall deposit. The source region for the deposits of units Pnp and Pnba as well as that for lava flows of unit Plo have been eroded and covered by younger lava flows.

Source regions for these older units have been subsequently eroded and covered by mid- to late Pleistocene banded lavas (unit Pnb) on the upper northwest flank and late Pleistocene lava flows (unit PI). The moderately to intensely hydrothermally altered lava flows and intervening breccias of the upper south flank (unit Pla) likely represent the vent region. The lavas and breccias of this unit are red, orange, and yellow in color and locally altered to clay. The unit is predominantly exposed high above the south flank glacier in the western canyon wall under a carapace of less altered, younger lava flows (units HPlb and HIs).

Compositionally banded lava flows (unit Pnb), exposed at about $4,000 \mathrm{ft}$ on the northwest flank, are similar chemically to the deposits of unit Pnba and may be broadly similar in age. The banded lavas have a bulk composition of 59.6 to 60.6 weight percent $\mathrm{SiO}_{2}$ (table 1); geochemical analyses of bands show that the darker bands are more mafic (58.4 weight $\% \mathrm{SiO}_{2}$ ) and the lighter bands more silicic $\left(61.2\right.$ weight $\left.\% \mathrm{SiO}_{2}\right)$. The banded appearance is chiefly the result of microlite density, with the darker bands having a greater microlite density than the more glassy and vesicular lighter bands. Whole-rock and band compositions form arrays on chemical plots that overlap many analyses of clasts from unit Pnba. The upper surface of these lava flows is littered with glacially transported, banded boulders chemically similar to the clasts found in the block-and-ash-flow deposits to the north (unit Pnba). The few reliable ages on units Pnb and Pnba and the possibility of significant glacial erosion of their upper parts creates uncertainty as to the duration and continuity of this episode of explosive activity.

Later Pleistocene volcanism was dominated by the extrusion of porphyritic andesite and low silica dacite lava flows (units HPbv, Pla, Plvc, PI, PIse, and HPIb) with little evidence of explosive activity. Thick exposures of lava flows in units Plse and $\mathrm{PI}$ display radiating columnar jointing, glassy texture, and masses of internal breccia indicative of interaction with water and ice during periods of extensive glacier cover. These flows form high cliffs perched atop Jurassic bedrock, especially on the western flank (unit PI), where lava flows encountered thick glacier ice in the valley of Indecision Creek. ${ }^{40} \mathrm{Ar} /{ }^{39} \mathrm{Ar}$ ages of the late Pleistocene lavas range from $89 \pm 6$ ka to $-5 \pm 16 \mathrm{ka}$.

\section{Holocene Lava Flows, Pyroclastic Flows, and Block-and-Ash Flows}

The predominantly non-explosive, effusive Pleistocene trend continued throughout the Holocene, during which basaltic-andesite to andesite lava flows (55.3-61.8 weight $\% \mathrm{SiO}_{2}$ ) covered almost half of the current edifice, especially on the northeast and eastern flanks. A bowl-shaped summit crater that cuts through Pleistocene and Holocene lava flows suggests an explosive excavation during the Holocene; however, a correlative explosion breccia or tephra deposit was not found. An ${ }^{40} \mathrm{Ar} /{ }^{39} \mathrm{Ar}$ age of $14 \pm 10$ ka was obtained from a Holocene flow (unit HIs) on the west flank. A flat-topped, valley-filling block-and-ash flow, likely the result of a collapsing lava flow or dome on the southeast flank, extends southeast of the main edifice to a distance almost $8 \mathrm{~km}$ from the summit crater (unit Hba). Less extensive deposits of pyroclastic flows and lahars partly fill a valley eroded into the earlier block-and-ash-flow deposits and extend slightly farther downslope to a distance of $9 \mathrm{~km}$ from the summit (unit $\mathrm{Hpd}$ ). A knob on the southeast flank (vent region marked as high point x5567 ft on U.S. Geological Survey [USGS] Ugashik A-3 topographic map; hereafter referred to as vent 5567) is likely the source region for the lava flows or dome feeding these block-and-ash- and pyroclastic-flow units.

\section{Geochemistry}

We analyzed 92 rocks, from all major lava-flow and pyroclastic units at the volcano, for both major oxide and trace-element composition 
(table 1). All lavas lie within the calc-alkaline range of Aleutian volcanic rocks (fig. 4). Prior to this study, reconnaissance work by Riehle (1990; written commun., 2000) included analyses of 13 samples that ranged from about 56 to 64 weight percent $\mathrm{SiO}_{2}$ (our recalculation with all iron reported as $\mathrm{FeO}$ ). These analyses are in the Alaska Geochemical Database (AGDB2; Granitto and others, 2013) as well as five additional samples collected by Betsy Yount.
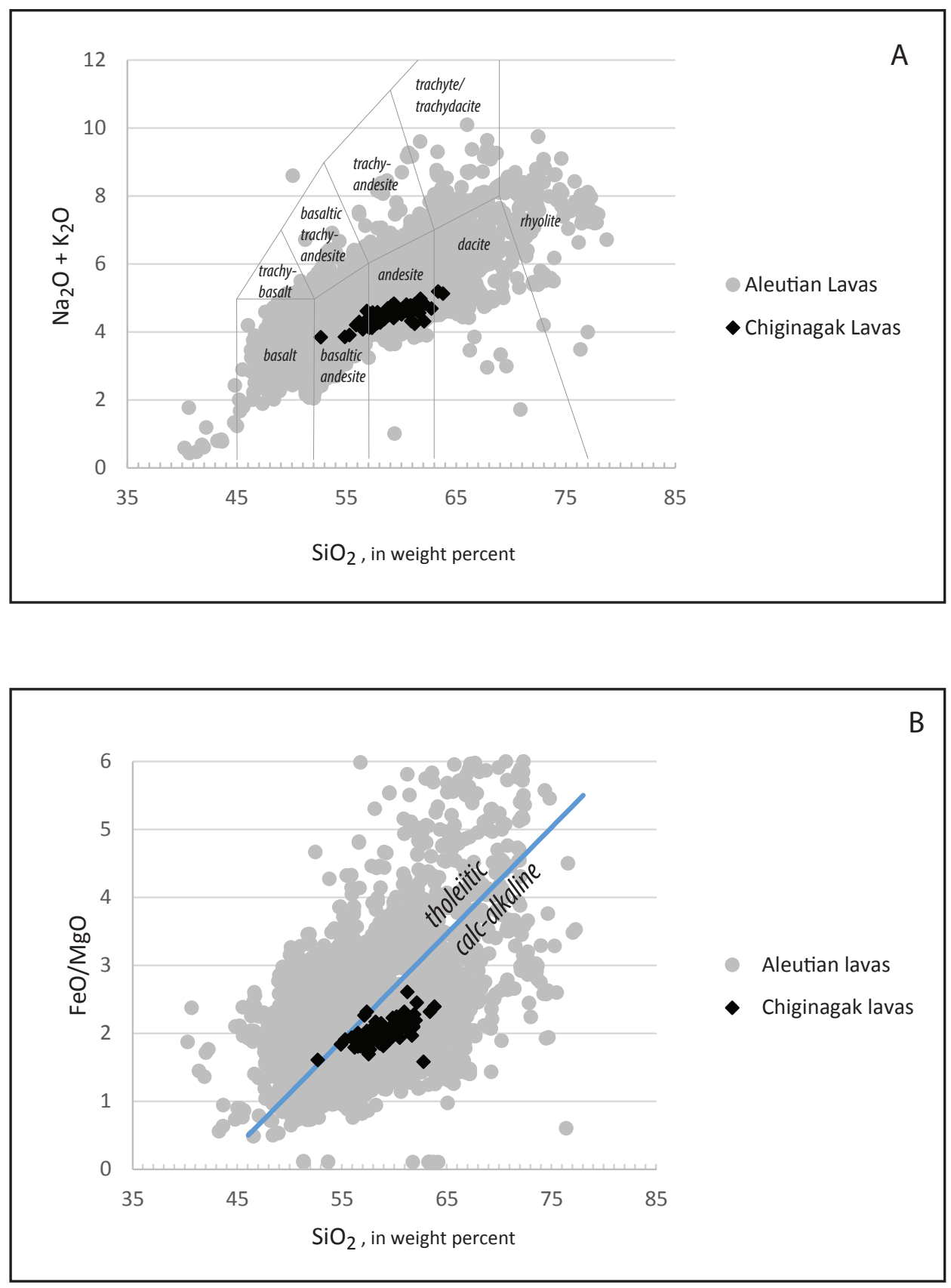

Figure 4. (A) Weight percent $\mathrm{SiO}_{2}$ vs. weight percent $\left[\mathrm{Na}_{2} \mathrm{O}+\mathrm{K}_{2} \mathrm{O}\right]$, and (B) weight percent $\mathrm{SiO}_{2}$ vs. [FeO/MgO], showing the calc-alkaline grouping of Chiginagak lavas (black diamonds) compared to Aleutian lavas (gray circles). Tholeiitic-calc-alkaline boundary from Miyashiro (1974). Aleutian data from Alaska Volcano Observatory geochemical database (Cameron and others, 2014), available online at https://www.avo. alaska.edu/geochem/index.php. 
Our samples of Mount Chiginagak lavas range from 54.9 to 63.8 weight percent $\mathrm{SiO}_{2}$ (figs. 4,5 , and 6 ), a range of silica similar to that in Riehle's and Yount's samples. The most mafic lava sampled is a basaltic andesite lava flow (unit Plo) interbedded in Pleistocene block-and-ash-flow deposits of unit Pnba and exposed in the cliffs above Indecision Creek on the western flank. We found no lava flows with silica content in the 51 to 53 weight percent range as reported in Miller and others (1998); however, many lava flows contain mafic enclaves, one of which was 52.6 weight percent $\mathrm{SiO}_{2}$ (fig.5). The most silicic lavas are slightly altered Pleistocene dacite (63.4 to 63.8; two samples from unit Pla), while the Holocene lavas have an intermediate range of 55.3-61.8 weight percent $\mathrm{SiO}_{2}$.
Chiginagak lavas are macroscopically similar (porphyritic; $0.5-1.5 \mathrm{~mm}$ phenocrysts of plagioclase, orthopyroxene, and clinopyroxene), but in addition to field relationships, they can also be distinguished by unique Ce/Sr ratios (fig. 7). Of map units of Pleistocene lava, two have relatively high Ce content (40-52 ppm), with some of the samples having relatively high $\mathrm{Sr}(>600 \mathrm{ppm})$. The bulk of Pleistocene units and all Holocene units plot within ranges of 25-35 ppm Ce and 325-525 $\mathrm{ppm}$ Sr. A few define linear arrays on Ce vs. $\mathrm{Sr}$ plots. Of the Holocene lava units mapped on the basis of field relationships, lavas of unit Hlf and associated blocks of unit $\mathrm{Hba}$ from vent 5567 on the east flank are distinguished from the summit-vent lavas (unit HIs) by having a lower and much narrower range of $\mathrm{Sr}$ values (fig. $7 \mathrm{~B}$ ).

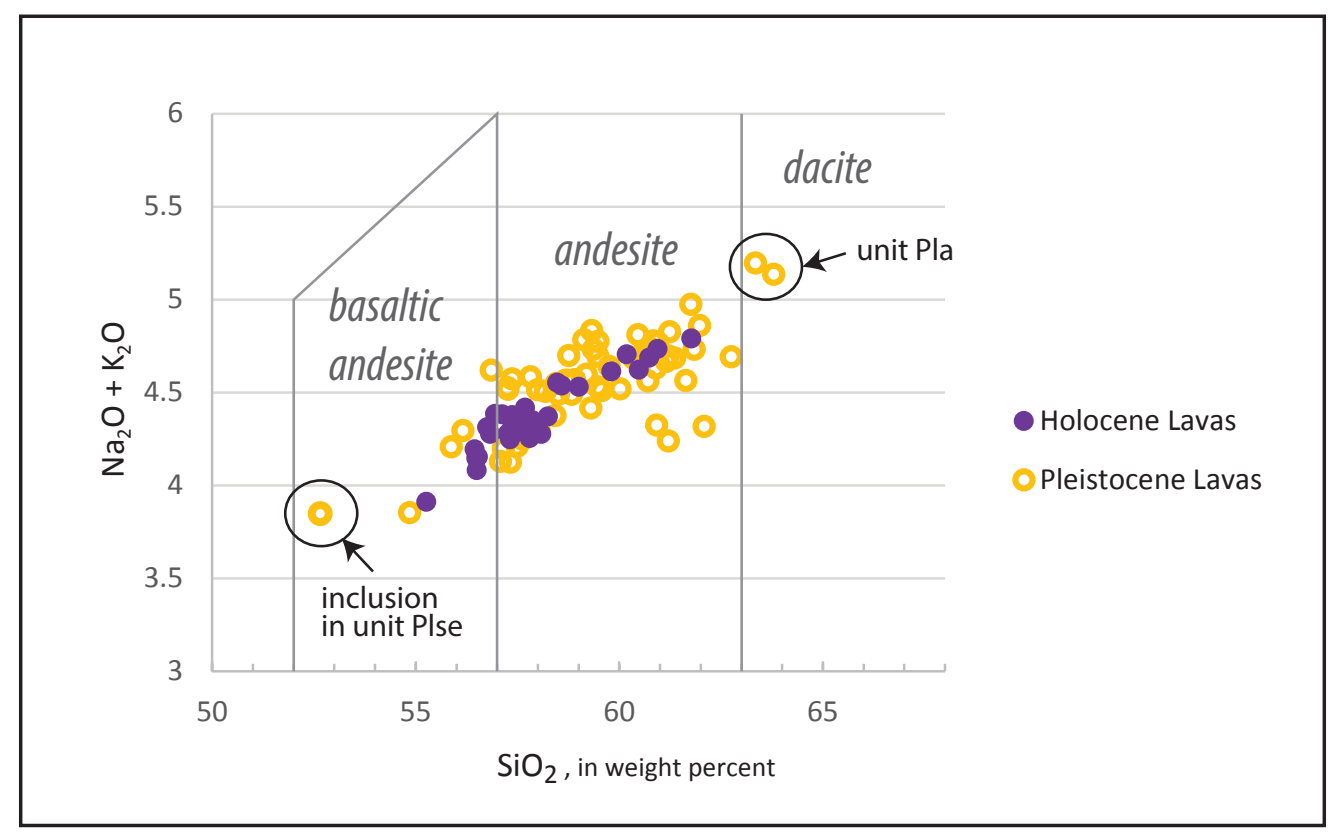

Figure 5. Weight percent $\mathrm{SiO}_{2}$ vs. weight percent $\left[\mathrm{Na}_{2} \mathrm{O}+\mathrm{K}_{2} \mathrm{O}\right]$ for Chiginagak lavas, grouped by age. End members are the dacitic lavas of unit Pla consisting of slightly to intensely hydrothermally altered lava flows, and a mafic enclave within an andesite lava flow of unit Plse. 

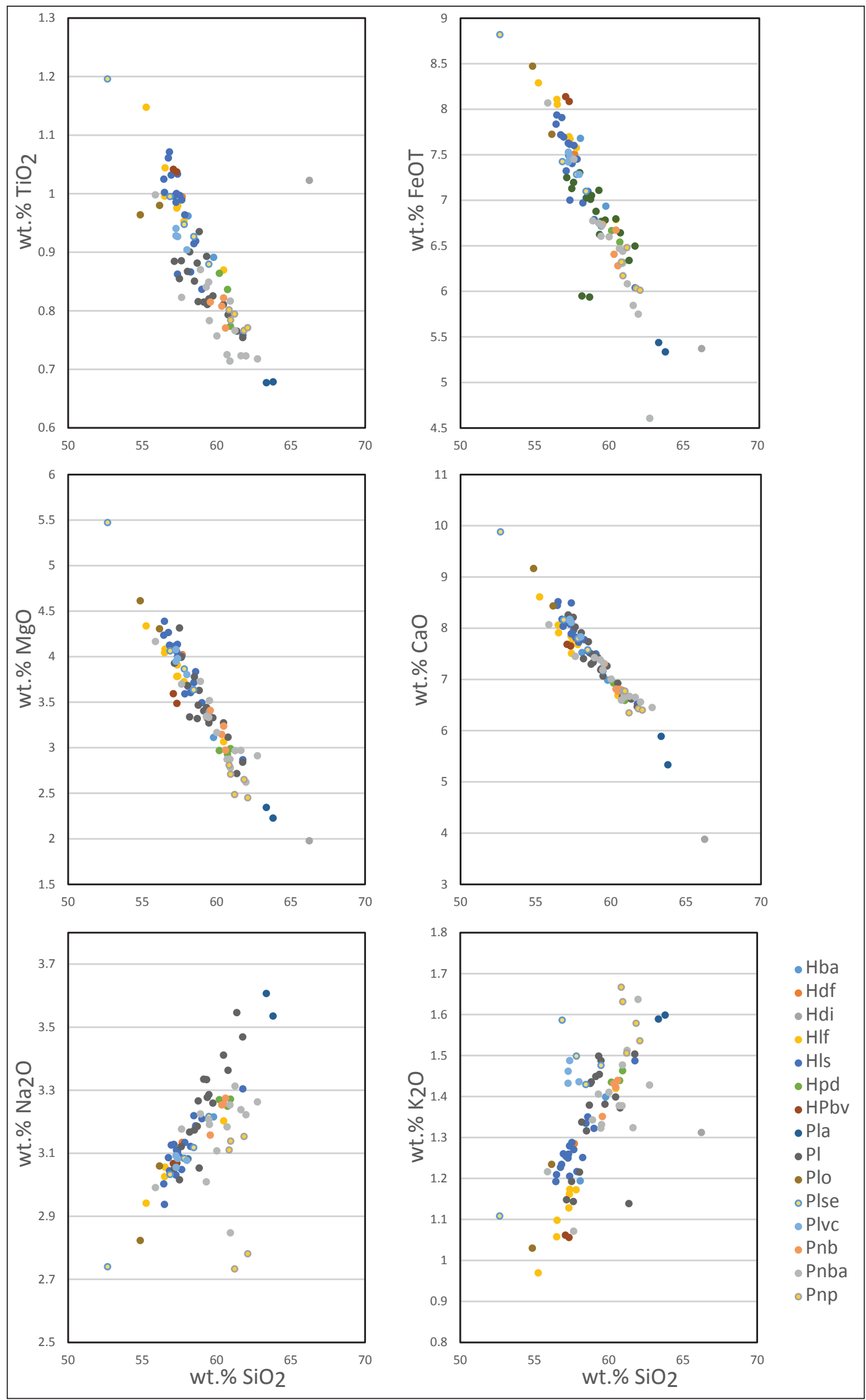

Figure 6. Harker diagrams for select major elements. All Chiginagak lavas collected during this study are represented. 

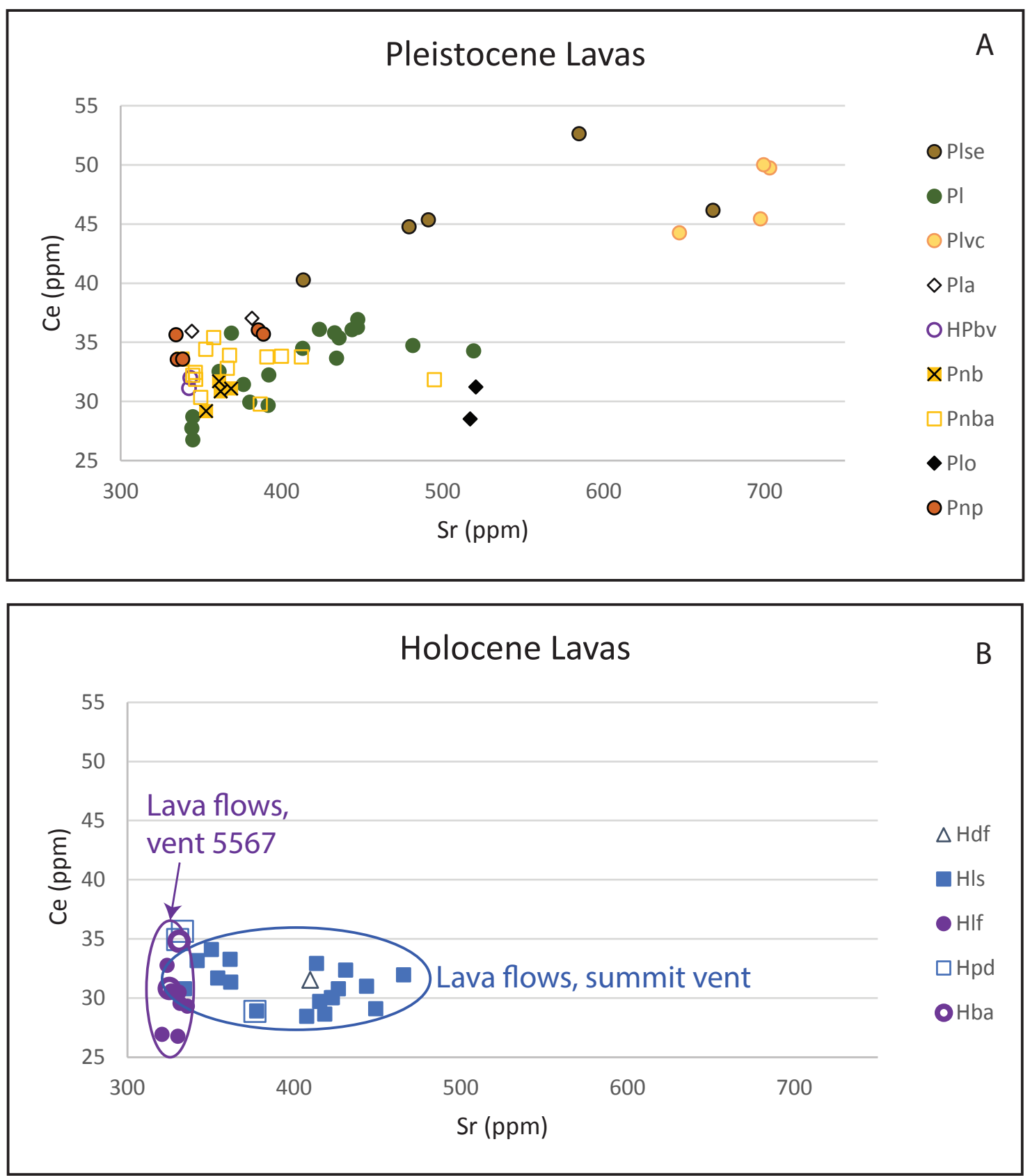

Figure 7. (A) Plot of Sr (ppm) vs. Ce (ppm) for Chiginagak Pleistocene lavas. (B) Plot of Sr (ppm) vs. Ce $(\mathrm{ppm})$ for Chiginagak Holocene lavas. Holocene lavas have a smaller range of $\mathrm{Sr}$ values as compared to Pleistocene lavas. 


\section{DESCRIPTION OF MAP UNITS}

\section{Alluvial, Colluvial, and Glacial Deposits}

Surficial deposits of non-volcanic origin are differentiated on the basis of origin and age. The entire Chiginagak region was covered by an extensive mountain ice sheet during the last glacial maximum about $20 \mathrm{ka}$ (Manley and Kaufman, 2002). Glaciers extended 40 to $60 \mathrm{~km}$ northwest of Chiginagak, close to the present shoreline of Bristol Bay, and roughly $150 \mathrm{~km}$ to the southeast onto the emergent Pacific continental shelf. Diverse gla- cial sediments including till, outwash, and glaciolacustrine sediments were deposited over broad areas. As glaciers waned, stream and slope processes reworked glacial deposits and underlying bedrock into colluvial and alluvial deposits. As they do today, glaciers probably remained on the upper slopes of the volcano, advancing and retreating as the climate fluctuated. Fresh, steep-sided moraines extending as far as $1 \mathrm{~km}$ beyond snouts of present glaciers mark the maximum advance during the Neoglacial period of the past few centuries. Figures cited at the end of the description provide illustrations of field relations or character of unit.

\section{GLACIERS AND PERENNIAL SNOW FIELDS (FIG. 8)}

DeBris-COVERED GLACIER-Poorly sorted, superglacial till covering much of the lower reach of the south flank glacier and a few areas near termini of glaciers on other flanks. The mantle on the south flank glacier is chiefly composed of hydrothermally altered rock and orange-brown clay eroded from the upper south flank and forms a series of convex-downstream concentric ridges (fig. 9).

Alluvium of active channels and floodplains (Holocene)—Chiefly cobble and pebble gravel and sand in upstream areas grading to sandy pebble gravel, sand, and sand and silt in downstream areas near Mother Goose Lake, Chiginagak Bay, and the upper Dog Salmon River.

Glacial till of late Neoglacial age (late Holocene)—Bouldery gravel and sand; very poorly sorted; in some locations the till forms sharp-crested moraines up to $1 \mathrm{~km}$ beyond margins of existing glacial termini. These likely date from the past several centuries. Includes patches of underlying lava flows too small to show at map scale (fig. 10).

Glacial outwash of late Neoglacial age (late Holocene)—Cobble and pebble gravel and sand, locally bouldery; crudely to moderately bedded; poorly sorted. Forms fans and channels fronting modern glaciers and moraines of late Neoglacial age. Includes small areas of late Neoglacial till and underlying lava flows too small to show at map scale. Merges downstream to alluvium of active channels (unit $\mathrm{Ha}$ ) and floodplains.

Colluvium and alluvium (Holocene and latest Pleistocene)—Colluvium and alluvium of valley-wall fans and landslide deposits; gravel and sand; very poorly sorted to poorly sorted; non-bedded to crudely bedded. Forms sheets and cones of talus and fans of alluvium and debris-flow deposits. Along brush-covered east side of Indecision Creek valley includes small areas of pre-Quaternary bedrock (unit JTu), block-and-ash-flow and related deposits of north flank (unit Pnba), and Pleistocene glacial deposits (units Pgt and Pgu) too small to show at map scale.

Glacial till (late Pleistocene)—Bouldery gravel and sand; massive; very poorly sorted. Weathering profile consisting of a few tens of centimeters of oxidized till and mantling finegrained sediment. Only mapped in one area on the northwest flank of the volcano where it lies on Pleistocene block-and-ash-flow deposits (unit Pnba). 
Glacial deposits, undifferentiated (late Pleistocene)—Undifferentiated deposits of till and glaciofluvial and glaciolacustrine deposits that bury Pleistocene block-and-ash-flow deposits (unit Pnba), Pleistocene lava flows, and bedrock (unit JTu) on the north flank. Also includes discontinuous mantle of chiefly fine-grained loessial sediments with interbedded tephra and buried soils.

\section{Products of Mount Chiginagak Volcano}

Eruptive products of Chiginagak volcano are subdivided into cone-forming andesitic and minor dacitic lava flows and associated breccias, deposits of block-and-ash pyroclastic flows derived from collapse of active lava domes or lava flows, and locally exposed pumiceous pyroclastic fall and flow deposits that may record the most explosive eruption in the volcano's history. The lava flows are divided further on the basis of age, geochemical differences, and source vent. Because the area was covered by extensive glaciers during the last major glaciation, we distinguish units that (1) predate or are synchronous with the last glaciation (that is, of Pleistocene age) and (2) those that postdate the recession of last-ice-age glaciers. Although not dated locally, regional studies show that the last glaciation peaked about $20 \mathrm{ka}$; glaciers had receded greatly by about 10 to $15 \mathrm{ka}$ (Kaufman and others, 2011; Barclay and others, 2009; Manley and Kaufman, 2002). The age boundary between the Pleistocene and Holocene Epochs is $11.7 \mathrm{ka}$ (Cohen and others, 2013), so without local age control it is not possible to determine whether postglacial deposits are of latest Pleistocene or Holocene age. For simplicity we refer to postglacial units as Holocene, realizing that some may be slightly older. Holocene lava-flow units include small areas of overlying till and outwash of late Neoglacial age too small to show at map scale.

hdi Debris-flow deposits of upper Indecision Creek (Holocene)—Poorly sorted gravel, sand, and orange-yellow clay; orange-brown sandy to silty-clay matrix; larger clasts are faceted andesite boulders, and gravel- to sand-sized angular clasts of hydrothermally altered andesite and gray dense andesite; forms terraces several meters above active channel along upper Indecision Creek. Probably originated from debris-covered glacier upstream (unit dcg). Varied terrace top elevations represent at least two ages of debris-flow deposits (fig. 11).

Hdf Pyroclastic-flow and lahar deposits along Chiginagak creek (Holocene) - Gray bouldery and cobbly diamicts with blocks of juvenile lava and clay-rich lahar deposits rich in hydrothermally altered debris that form small terraces along informally named Chiginagak creek southeast of the volcano. Along upper Chiginagak creek, gray, sandy-matrix diamicts overlie yellow to orange-brown, clayey, massive lahar deposits. We infer that the clayey lahar deposits (individual units on the order of 1 to $2 \mathrm{~m}$ thick) were generated by debris avalanches that contained sufficient water to transform into a lahar and the overlying gray diamict originated in collapses of growing lava domes or flows (fig. 12). Geochemical analysis of a block from the gray diamict resembles that of lava of unit HIs. Upper gray diamicts up to a few meters thick; clay-rich lahar deposits more than $10 \mathrm{~m}$ thick. LAVA Flows From SUMMit Vent (HOLOCENE) — Rubbly-topped andesite (56.4-59.0 weight $\% \mathrm{SiO}_{2}$; seventeen analyses) lava flows that form a nearly continuous apron on the north and east flanks and one flow on upper west flank. Lava is porphyritic and contains variable proportions of $0.5-1.5 \mathrm{~mm}$ plagioclase, hypersthene, clinopyroxene, and oxides. Flow surfaces are modified by glacial erosion and deposition within the limit of neoglacial advances, but are typically rubbly and blocky beyond. Southernmost flow on east flank overlies lava flow from a vent on the southeast flank (unit HIf). Lavas of the summit vent have a wider range of $\mathrm{Sr}$ values compared to lavas from vent 5567 (unit Hlf), (figs. 7 and 13). 
HIf LAVA FLOWS FROM VENT 5567 ON SOUTHEAST FLANK (HOLOCENE)—Rubbly-topped andesite (55.3-60.5 weight \% $\mathrm{SiO}_{2}$; eight analyses) lava flows that form a high point about $1.4 \mathrm{~km}$ southeast of summit crater (x5567 ft on USGS Ugashik A-3 topographic map) and a series of flow lobes that surround portions of Pleistocene lava flows (units Plse and PI) on the southeast and south flanks. Lava is porphyritic and contains variable proportions of $0.5-1.5 \mathrm{~mm}$ plagioclase, hypersthene, augite, and minor olivine and oxides. Northernmost lava flow underlies the southern margin of summit lava flows (unit HIs). Detterman and others (1987b) map vent 5567 as a lava dome surrounded by lava flows, but we find that the vent lavas form flows that reach the base of east the flank. Two prismatically jointed blocks (57.4 and 58.1 weight $\% \mathrm{SiO}_{2}$ ) that are chemically similar to lava of this unit lie on deposits of block-and ash flows of Bear valley (unit $\mathrm{Hba}$ ). We infer that they are blocks emplaced by late pyroclastic flows or rockfalls from active lava flows of vent 5567. Geomorphic relations at the head of north Bear valley drainage show that emplacement of lava flows of unit HIf followed erosion of a valley through deposits of unit $\mathrm{Hba}$ and passage of pyroclastic flows and lahars of unit Hpd (fig. 14).

Deposits of PyROCLASTIC Flows AND LAHARS (Holocene)—Lahar and poorly sorted pyroclastic-flow deposits consisting of andesite blocks (25\% are vesicular) in a loose, pink to gray, sandy matrix. Most vesicular blocks are less than $10 \mathrm{~cm}$, and the dense, juvenile, prismatically jointed blocks ( 60.2 to 60.8 weight $\% \mathrm{SiO}_{2}$ ) are larger, up to $1 \mathrm{~m}$. Terraced surfaces of $\mathrm{Hpd}$ lie along the northeast side of Bear valley, where they are inset below the upper surface of block-and-ash-flow deposits of Bear valley (unit $\mathrm{Hba}$ ), as well as in lower Bear valley, approximately 1,600 $\mathrm{m}$ farther down valley than the toe of unit $\mathrm{Hba}$. The deposit is discontinuously mantled by unmapped, fine-grained loessial deposits with interbedded tephras and buried soils. A small, isolated outcrop of a similar diamict of possibly equivalent age is found along a tributary of Volcano Creek on the lower north flank surrounded by unit Pgu, where approximately $2 \mathrm{~m}$ of soil and tephra overlie a 1-m-thick gray, sandy, polylithic, matrix-supported lahar with a base deposit consisting of a pink monolithic pyroclastic-flow deposit with a variably cemented matrix. An organic layer in this upper mantle has a radiocarbon age of 3,110 \pm 80 yBP (fig. 3).

Hba Deposits of block-And-ash flows and lahars of Bear valley (Holocene) - Bouldery andesitic (58.1 and 59.8 weight $\% \mathrm{SiO}_{2}$; two analyses) diamicts with sandy matrix; poorly sorted, non-stratified; commonly with prismatically jointed clasts; clasts dense to vesicular; minor amount of hydrothermally altered clasts. Limited exposures suggest diamicts comprise numerous flow units on order of 1-3 m thick. They partly fill the unnamed stream valley on the east flank (which we informally call Bear valley) up to $8 \mathrm{~km}$ distant from the presumed source at vent 5567 . Likely related to collapse of growing lava dome or active lava flows. If lava-dome extrusion at vent 5567 fed the block-and-ash flows, that dome is buried by later lava flows of unit HIf. Stratigraphic relationship of block-and-ash-flow deposits with unit HIf is obscured by erosion and deposition from neoglacial advance, but we infer that both originated from eruptions near flank vent 5567. Geomorphic relations show that fill of unit $\mathrm{Hba}$ was eroded by stream along north side of valley prior to emplacement of lobe of unit Hif at site 05JRSCH051. Riehle (1990) believed that much of the fill in Bear valley was a lava flow (our unit Plbv), except along the north side of the valley, and was only thinly mantled by block-and-ash-flow deposits. However, we find substantial cover of deposits and only limited outcrop of the lava flow. Above about $1,000 \mathrm{ft}$ elevation, surface is largely barren of vegeta- 
tion and reworked by solifluction and other surface processes. At lower elevations, the unit is covered by a discontinuous mantle of sand, silt, and organic material that contains a few thin tephra layers. The amount of soil development (tens of centimeters of oxidation) suggests unit is probably of early Holocene age. Overlies lava flow of Holocene or Pleistocene age (unit HPbv) exposed locally along south margin of Bear valley. Undated (figs. 14 and 15).

Andesite lava flow of Bear valley (late Pleistocene or Holocene)—Andesite (57.1 and 57.3 weight $\% \mathrm{SiO}_{2}$; two analyses) lava flow that underlies block-and-ash-flow deposits (unit $\mathrm{Hba}$ ) along south margin of Bear valley. Plagioclase is the dominant mineral phase; 1-1.5 mm plagioclase phenocrysts with less abundant $0.5 \mathrm{~mm}$ clinopyroxene and orthopyroxene. Chemical composition of relatively high $\mathrm{TiO}_{2}$ and $\mathrm{FeO}$ and low $\mathrm{K}_{2} \mathrm{O}, \mathrm{Ba}$, and $\mathrm{Sr}$ poorly matches other units. Riehle (1990) interpreted this flow as Holocene, but, owing to poor exposure that limits assessment of degree of glacial erosion prior to burial by deposits of block-and-ash flows, we leave open the possibility of late Pleistocene age. Undated (fig. 16). Hydrothermally altered lava flows and breccias (late Pleistocene to Holocene)— Slightly to intensely hydrothermally altered lava flows and lava breccias that form the uppermost edifice on the south flank and the highest point on the crater rim. This unit is younger and has more steeply dipping beds than the more severely altered lava flows and intervening breccias of unit Pla, also on the south flank. Some may represent near-vent equivalent of summit lava flows of unit HIs. Unsampled (figs. 17 and 18).

Plse Andesite lava flows of southeast flank (late Pleistocene)—Porphyritic andesite (52.7 to 59.5 weight $\% \mathrm{SiO}_{2}$; five analyses) lava flows and intervening breccias that form broad, glacially eroded ridges on lower southeast flank; contain abundant phenocrysts and microphenocrysts of plagioclase, hypersthene, augite, and oxides; also abundant mafic enclaves (one analysis, 52.7 weight $\% \mathrm{SiO}_{2}$ ). Lava characterized by high $\mathrm{Ce}$ ( 40 to $53 \mathrm{ppm}$ ); some samples also have high $\mathrm{Sr}(>500 \mathrm{ppm})$ (fig. 7$) ;{ }^{40} \mathrm{Ar} /{ }^{39} \mathrm{Ar}$ age of $24 \pm 8 \mathrm{ka}$. Overlain by lava flows of flank vent 5567 (unit HIf).

Andesite lava flows of south, west, and northwest flanks (late Pleistocene)—Porphyritic andesite (57.2-61.8 weight $\% \mathrm{SiO}_{2}$; eighteen analyses) lava flows containing abundant $1-1.5 \mathrm{~mm}$ plagioclase; smaller and less abundant hypersthene, and augite to $0.5 \mathrm{~mm}$; abundant oxide growth in the pyroxenes; common fine-grained mafic enclaves. Includes some thick (up to $350 \mathrm{~m}$ ) ice-contact lava flows along the east side of Indecision Creek valley that were emplaced against east margin of a valley-filling glacier. Ice-contact flows contain large masses of breccias, quenched glassy lava, discontinuous pods of intensely jointed lava, high cliffs displaying fans of radiating columnar joints, and numerous faults, indicative of interaction with water and ice. Also includes lava flows on south and north-northwest flanks that overlie deposits of Pleistocene block-and-ash flows (unit Pnba). Forms a lava bench on the northwest flank consisting of $>1$-m-thick stacked lava flows. Lava flows have glacially eroded tops and are covered discontinuously by deposits of till (unit Pgt) too small to map. ${ }^{40} \mathrm{Ar} /{ }^{39} \mathrm{Ar}$ ages of $15 \pm 11,38 \pm 9,44 \pm 18,54 \pm 13,55 \pm 8,64 \pm 8,72 \pm 9$, and $75 \pm 3 \mathrm{ka}$ (table 2) and chemical diversity suggest eruptions occurred during several episodes in late Pleistocene time (figs. 18 and 19).

Pluc Andesite lava flows of upper Volcano Creek (late Pleistocene)—Porphyritic andesite (57.3 to 57.6 weight $\% \mathrm{SiO}_{2}$; four analyses) containing phenocrysts of plagioclase to $1.5 \mathrm{~mm}$; common mafic enclaves. Form glacially eroded ridge west of upper Volcano Creek; lava char- 
acterized by high Ce (44-50 ppm) and high $\mathrm{Sr}(647-703 \mathrm{ppm})$ (fig. 7) and relatively high $\mathrm{K}_{2} \mathrm{O}$ (1.43 to 1.49 weight \%) for silica content (fig. 6). Overlies deposits of block-and-ash flows and lahars of north flank (unit Pnba). ${ }^{40} \mathrm{Ar} /{ }^{39} \mathrm{Ar}$ ages of $47 \pm 10$ and $63 \pm 6 \mathrm{ka}$.

Pla Hydrothermally altered lava flows (late Pleistocene) - Weakly to intensely hydrothermally altered porphyritic low silica dacite (63.4 and 63.8 weight $\% \mathrm{SiO}_{2}$; two analyses; most silicic analyses of any sampled Chiginagak rocks) lava flows and intervening breccias of the upper south flank; some thick, massive outcrops may represent lava domes or dome breccia; gray, red, orange, and yellow in color; locally altered to clay and contains minor gypsum. Fresher lava contains abundant phenocrysts of plagioclase, hypersthene, and augite as well as common mafic enclaves. This unit is prominently exposed along the canyon walls flanking the south glacier under a carapace of less altered lava flows of the younger unit PI; also underlies less-altered lava flows and lava breccias of unit HPlb in walls of summit crater. ${ }^{40} \mathrm{Ar} /{ }^{39} \mathrm{Ar}$ age of $89 \pm 6 \mathrm{ka}$ in the east wall above south flank glacier. Rockfalls and rock avalanches from this unit and lava breccias of unit HPIb create thick, orange-brown, superglacial debris mantle (unit dcg) (figs. 17 and 18).

Pnb Banded lavas of northwest flank (middle to late Pleistocene)—Porphyritic, vesicular to dense, and locally banded, andesite (59.6 to 60.6 weight $\% \mathrm{SiO}_{2}$; four analyses) lava flows and breccias. Phenocrysts chiefly $1 \mathrm{~mm}$ plagioclase with polymineralic aggregates of plagioclase, clinopyroxene, and orthopyroxene; abundant oxides throughout. Overlain by a lava flow of south and west flank (unit Pl) that, in turn, is littered with abundant glacially transported and strikingly banded blocks similar to lava flow. Analysis of darker-colored band is 58.4 weight percent $\mathrm{SiO}_{2}$; two lighter-colored bands are 61.2 weight percent $\mathrm{SiO}_{2}$. Lighter-colored bands have glassy groundmass while darker-colored band has microlite-rich groundmass. Source of transported lava lies upslope largely under glacier ice, but perhaps exposed below summit ridge. Blocks and in-situ lava are compositionally similar to clasts in north flank block-and-ash-flow deposits (unit Pnba) and suggest that block-and-ash flows and banded lavas may date from same eruptive period. An 40Ar/39Ar age of $115+/-30 \mathrm{ka}$ was obtained from a light-gray, slightly vesicular lava within this unit (fig. 20).

Pnba Block-AND-ASH-Flow and lahar Deposits of NORTh Flank (middle to Late PleistoCENE) - Bouldery and cobbly, very poorly sorted diamicts of dense to vesicular andesite clasts in a sandy matrix; clasts commonly prismatically jointed. Clasts range from 57.6 to 62.8 weight percent $\mathrm{SiO}_{2}$ (nine analyses). Lava contains abundant $1 \mathrm{~mm}$ subhedral plagioclase and orthopyroxene with smaller and less abundant clinopyroxene; glassy groundmass contains $<0.2 \mathrm{~mm}$ plagioclase laths; abundant oxide growth in pyroxenes. The upper approximately $150 \mathrm{~m}$ of deposit is accessible for study; individual beds are one to several meters thick; locally indurated, probably by glacial compaction and silica cementation. Chemical diversity of upper part of unit suggests emplacement over several eruptive periods. Lower part of the unit is largely inaccessible in cliffs on east side of Indecision Creek valley, but appears to be formed of multicolored sequences of sandy and finer-grained, well-stratified deposits as well as diamicts. We do not know how similar upper and lower parts are in age and origin. Great thickness of sequence (more than $300 \mathrm{~m}$ ) and height above floor of Indecision Creek valley $(600 \mathrm{~m})$ suggests that unit may represent sediment that accumulated against thick glacier in valley. Chemical similarity of analyzed clasts from upper part of unit with banded lava flows of north flank (unit Pnb) suggests they may date from same general eruptive period during 
which active lava flows or lava domes on the upper northwest flank were generating large amounts of debris. ${ }^{40} \mathrm{Ar} /{ }^{39} \mathrm{Ar}$ age of $189 \pm 14$ ka was obtained from a prismatically jointed lava block within a -5 -m-thick flow unit near the eroded top of the unit, just below $-30 \mathrm{~m}$ of till (figs. 21 and 22).

Pnp Pumice-rich fall and flow deposits of north flank (middle Pleistocene)—More than 10-m-thick (base not exposed) deposit of light-gray to yellow, high-silica andesite (60.8 to 62.1 weight $\% \mathrm{SiO}_{2}$; seven analyses) pumice fall and flow deposits. Deposit composed chiefly of pumiceous lapilli and ash, with less abundant component of small bombs, dense gray clasts, and accidental fragments. Known only from single exposure along tributary of Volcano Creek where it underlies block-and-ash-flow and lahar deposits of north flank (unit Pnba), whose base is rich in pumiceous clasts and breadcrust bombs. Their contact is disconformable but, owing to geochemical similarity to samples from units Pnba and Pnp, may not signify a long time break (fig. 22).

Basaltic andesite lava flows of north flank (middle Pleistocene) - At least two basaltic andesite lava flows (54.9 and 56.2 weight $\% \mathrm{SiO}_{2}$; two analyses) that lie within blockand-ash-flow deposits of north flank (unit Pnba); exposed in cliffs above Indecision Creek, approximately $100 \mathrm{~m}$ from eroded top of block-and-ash-flow deposits. Abundant $1 \mathrm{~mm}$ plagioclase, orthopyroxene, and clinopyroxene in a dark gray sugary groundmass. An unsampled lava flow that forms an inaccessible bench below main flow is included in unit, but its stratigraphic position is not well constrained. A diamict of radially fractured blocks in a sandy matrix, which crops out about $400 \mathrm{~m}$ north of exposure of upper lava flows and appears to be interbedded in block-and-ash flows of north flank (unit Pnba), has a basaltic andesite composition (55.9 weight $\% \mathrm{SiO}_{2}$; one analysis) similar to that of the lava flows in unit and is likely a fragmental deposit related to it. Block in diamict yielded a ${ }^{40} \mathrm{Ar} /{ }^{39} \mathrm{Ar}$ age of $251 \pm 6$ ka (fig. 21).

\section{Pre-Quaternary Bedrock}

JTu Bedrock, undifferentiated-Chiefly Upper Jurassic Naknek Formation sandstone and siltstone (units Jns and Jnst of Detterman and others, 1987a), as well as intrusive, hypabyssal, and extrusive igneous rocks of Miocene to Pliocene age and nonmarine sedimentary rocks of Eocene age. Includes discontinuous and unmapped mantle of alluvial, colluvial, and glacial deposits. 


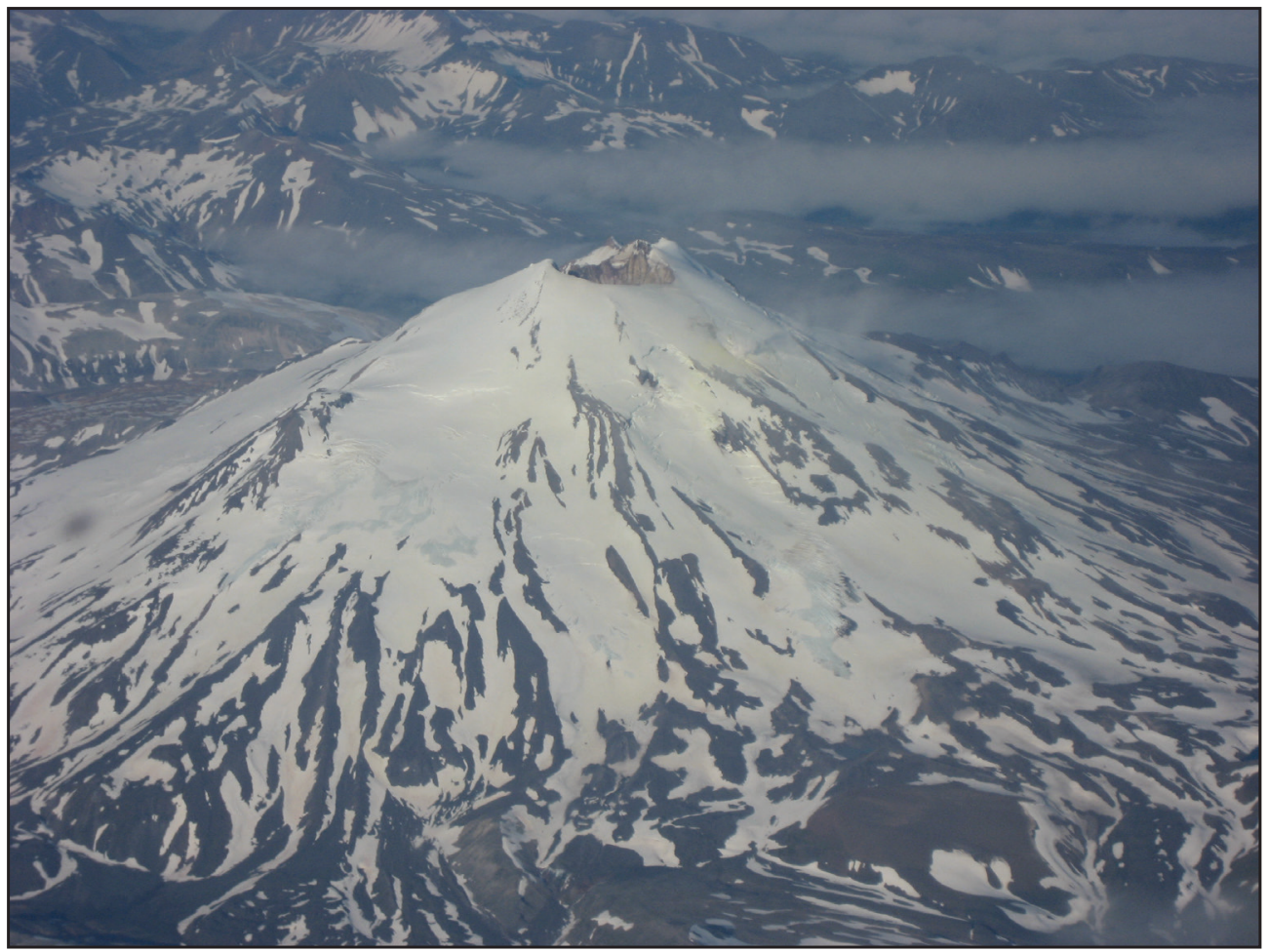

Figure 8. Aerial view of Chiginagak volcano, showing glaciers and perennial snow fields (unit g); view is to the west. Photo by J. Morris, August 1, 2008. AVO image database link: http://www.avo.alaska.edu/images/image.php?id=14738

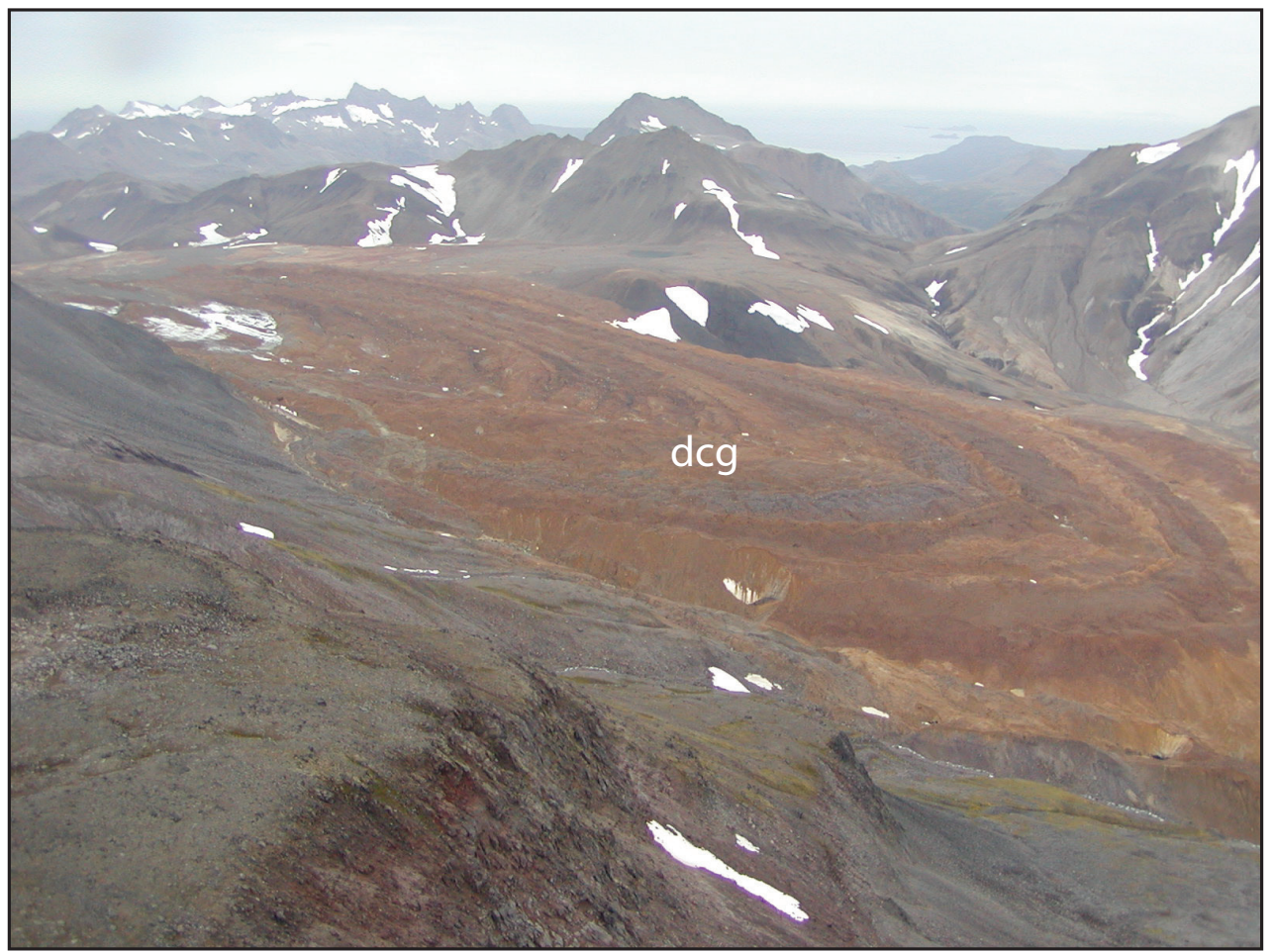

Figure 9. Debris-covered glacier (unit dcg) on the south flank; view is to the southeast toward Chiginagak Bay. Photo by J. Schaefer, August 20, 2005. AVO image database link: http://www.avo.alaska.edu/images/image.php?id=3349 


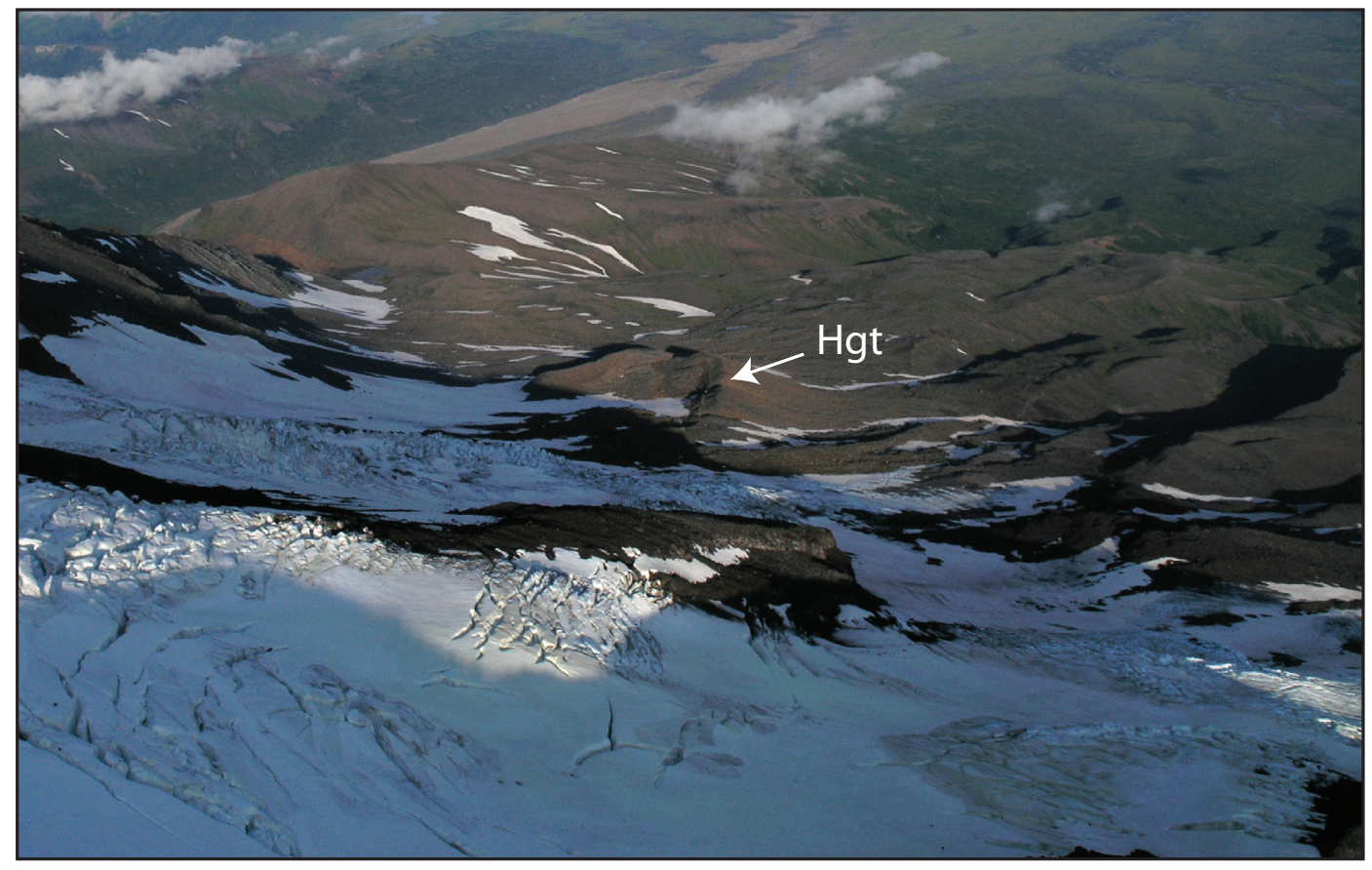

Figure 10. Glacial till of late Neoglacial age (upper Holocene) forming a sharp-crested moraine on the north flank (unit Hgt). Photo by J. Schaefer, August 29, 2008. AVO image database link: http:// www.avo.alaska.edu/images/image. php?id=56364

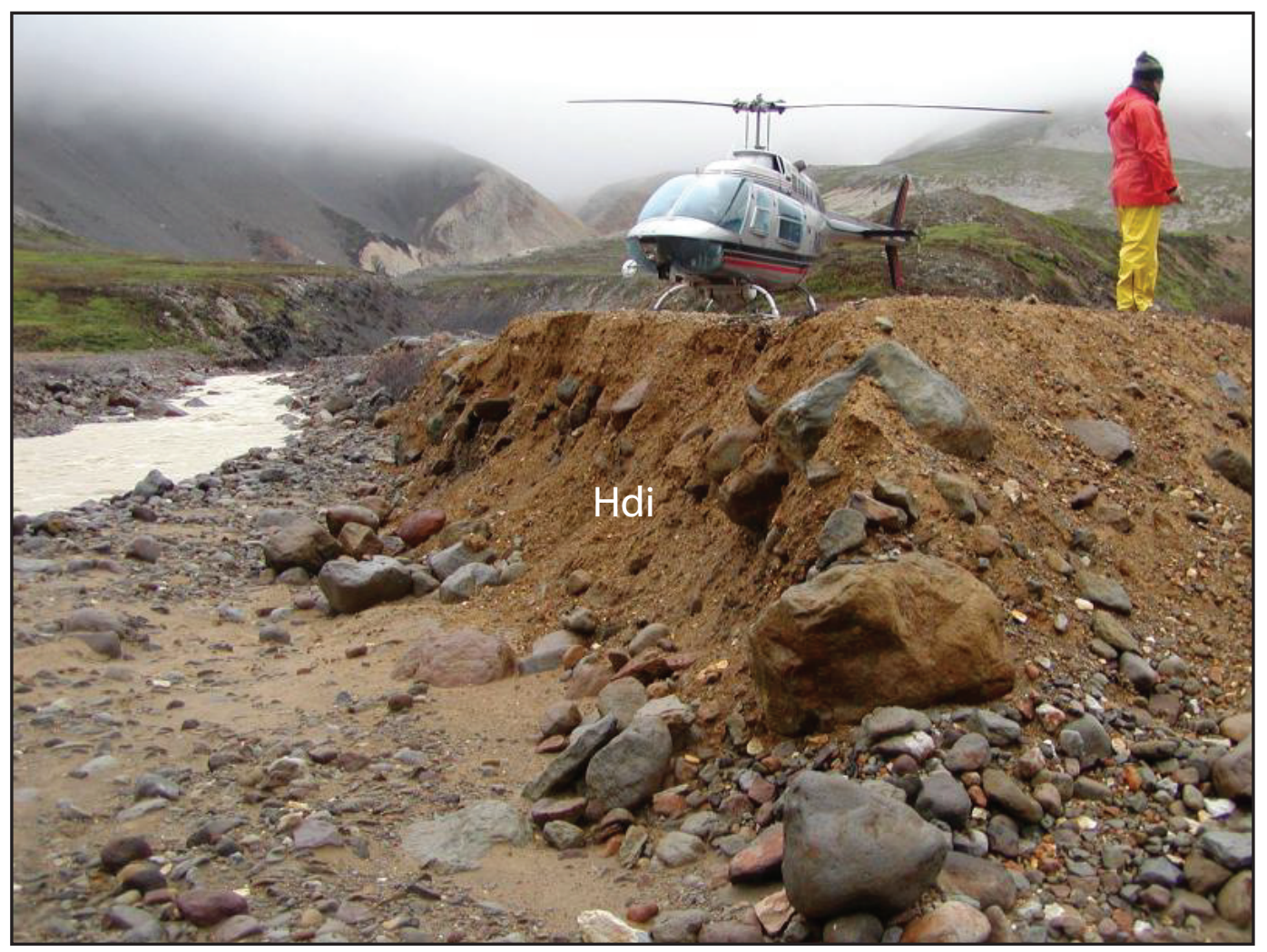

Figure 11. U.S. Geological Survey geologist Willie Scott stands atop an orange-colored terrace of an old debris-flow deposit preserved alongside the current drainage of upper Indecision Creek (unit Hdi), downstream of the south flank glacier. Photo by J. Schaefer, August 21, 2006. AVO image database link: http://www.avo.alaska.edu/images/image.php?id=11019 


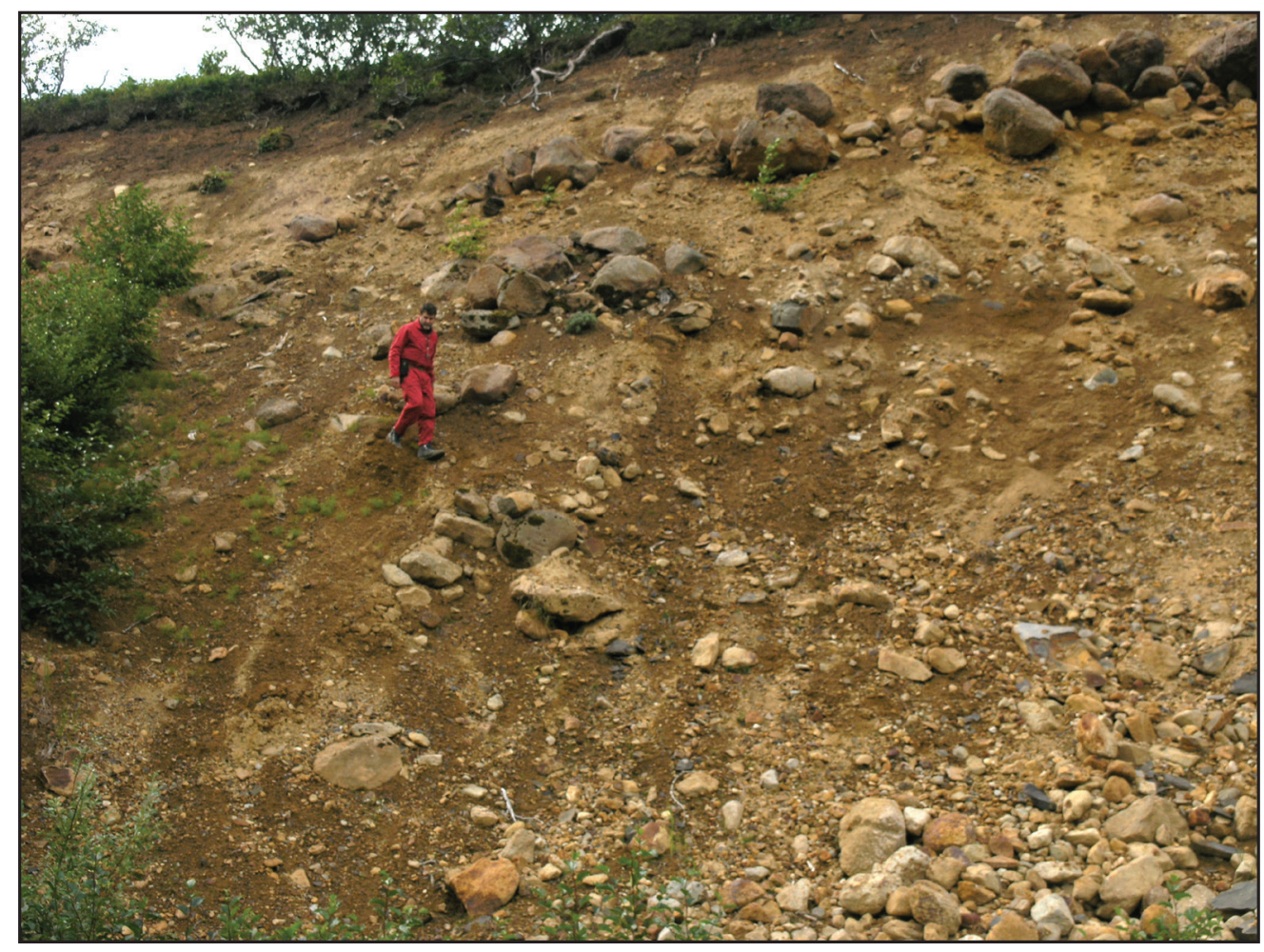

Figure 12. Holocene pyroclastic-flow and lahar deposits along Chiginagak Creek (unit Hdf). Photo by J. Schaefer, August 24, 2008. AVO image database link: http://www.avo.alaska. edu/images/image. php?id=90711

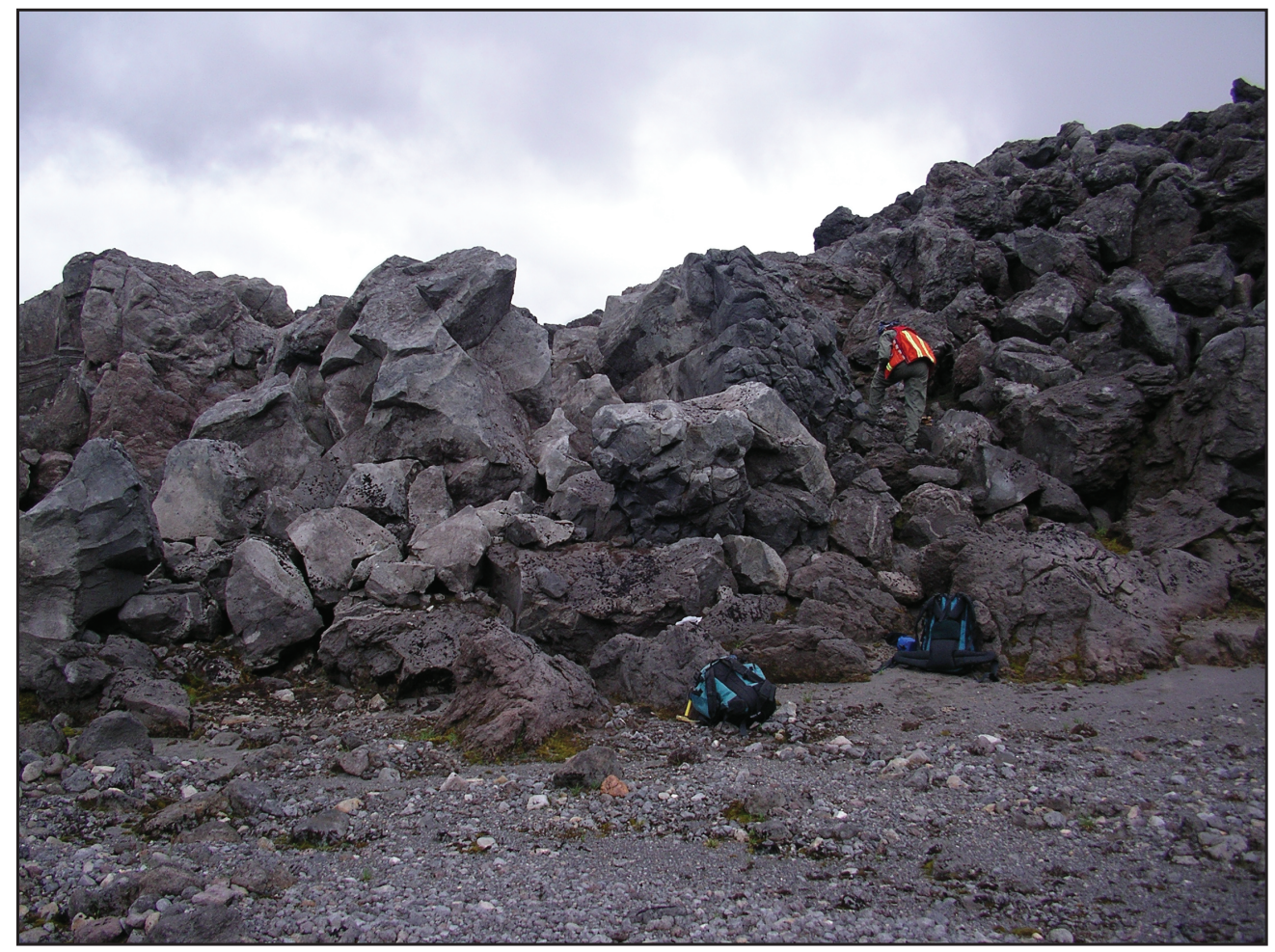

Figure 13. Blocky andesite lava flow on the east flank of Chiginagak volcano (unit HIs). Photo by W. Scott, August 21, 2004. AVO image database link: http://www.avo.alaska.edu/images/ image. php?id=904 


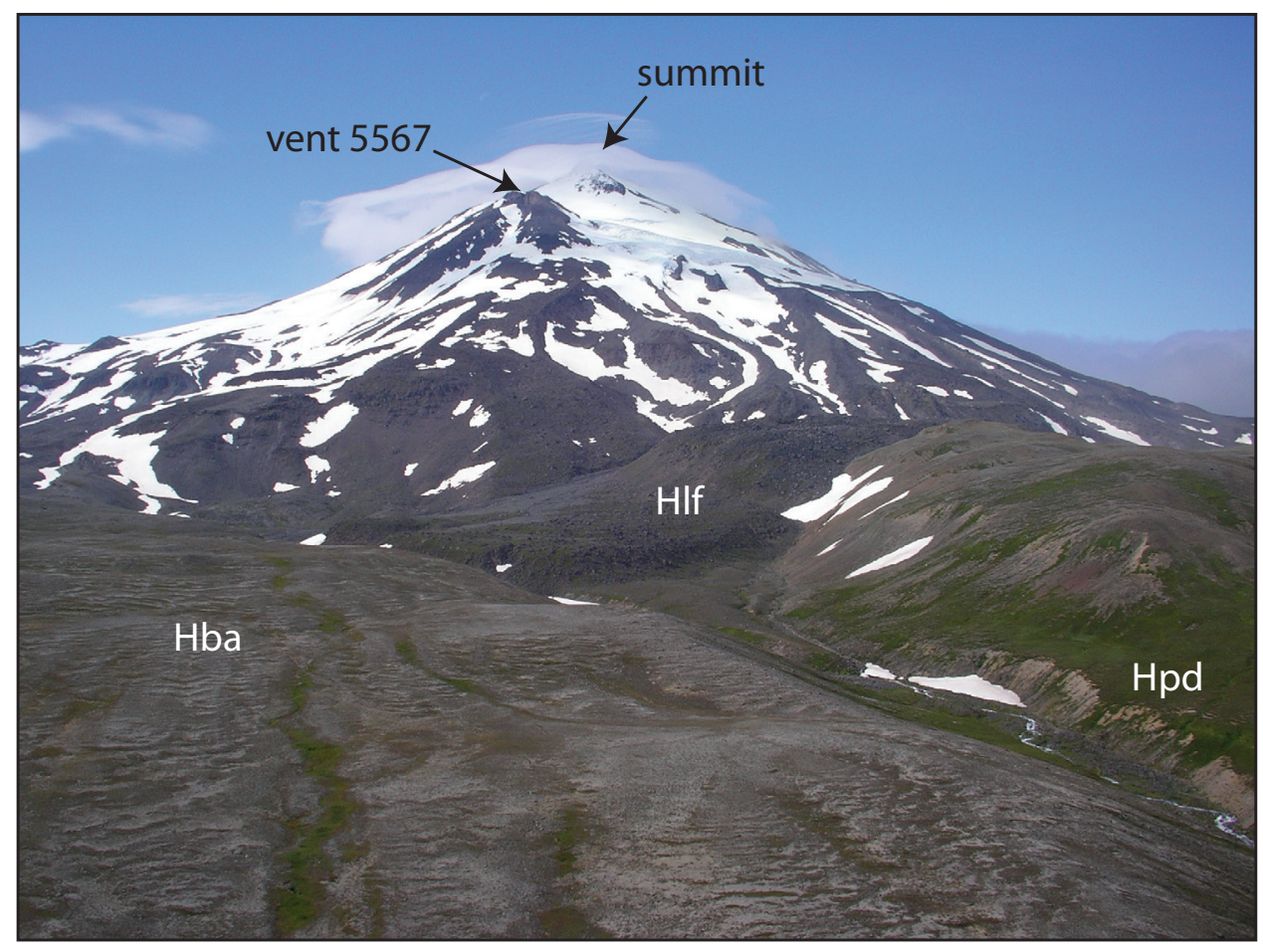

Figure 14. View to the northwest, up Bear valley, showing vent 5567 and associated lava flows (HIf) and block-and-ash flow (Hba); pyroclastic-flow and debris-flow deposits (Hpd) overlie Naknek Formation siltstone north of unit Hba. Photo by W. Scott, August 24, 2008. AVO image database link: http://www.avo.alaska.edu/images/image. php?id=91681

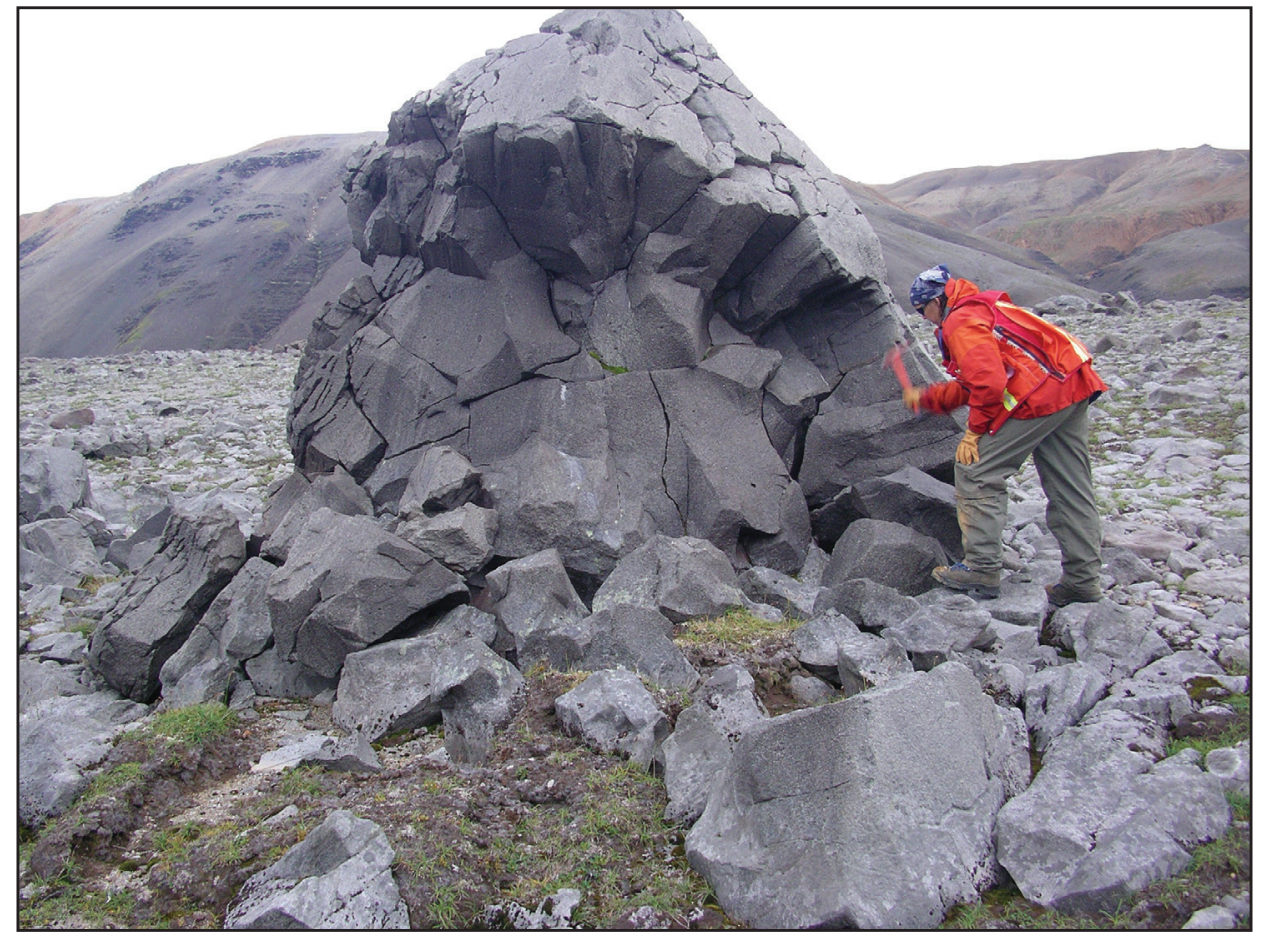

Figure 15. Geologist Janet Schaefer (DGGS/AVO) collects a sample from a prismatically jointed andesite block atop the upper Bear valley block-and-ash-flow deposit (unit $\mathrm{Hba}$ ). Photo by W. Scott, August 21, 2004. AVO image database link: http://www.avo.alaska. edu/images/image. php?id=920 


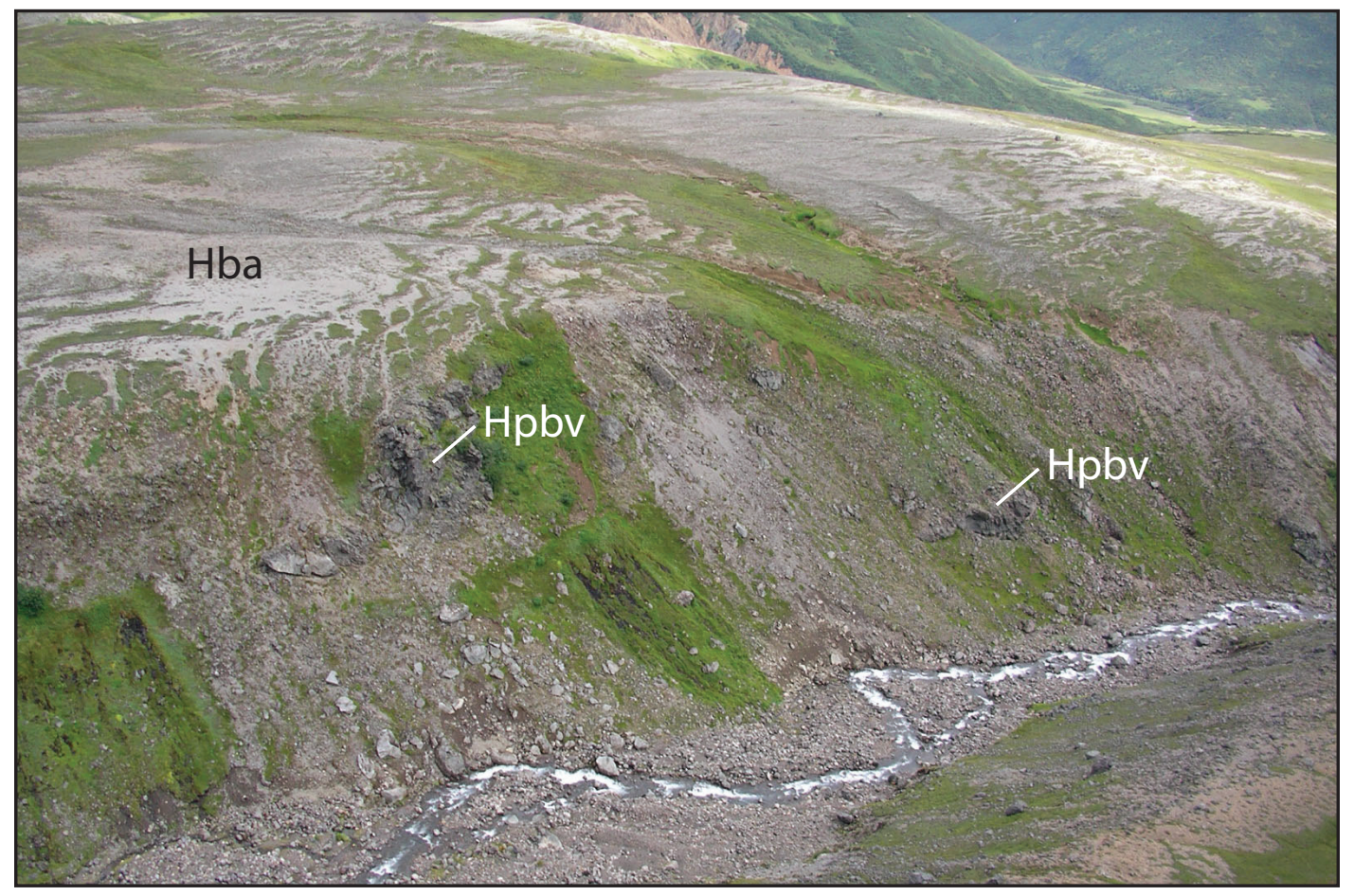

Figure 16. Andesite lava flow (unit Hpbv) exposed in a stream cut on the west side of the Bear valley; the lava flow is overlain by a block-and-ash-flow deposit, unit Hba. Sample 04JSCH023 (table 1) was taken from the outcrop of Hpbv on the left side of the photograph. Photo by W. Scott, August 24, 2004. AVO image database link: https://avo.alaska.edu/images/image.php?id=1337

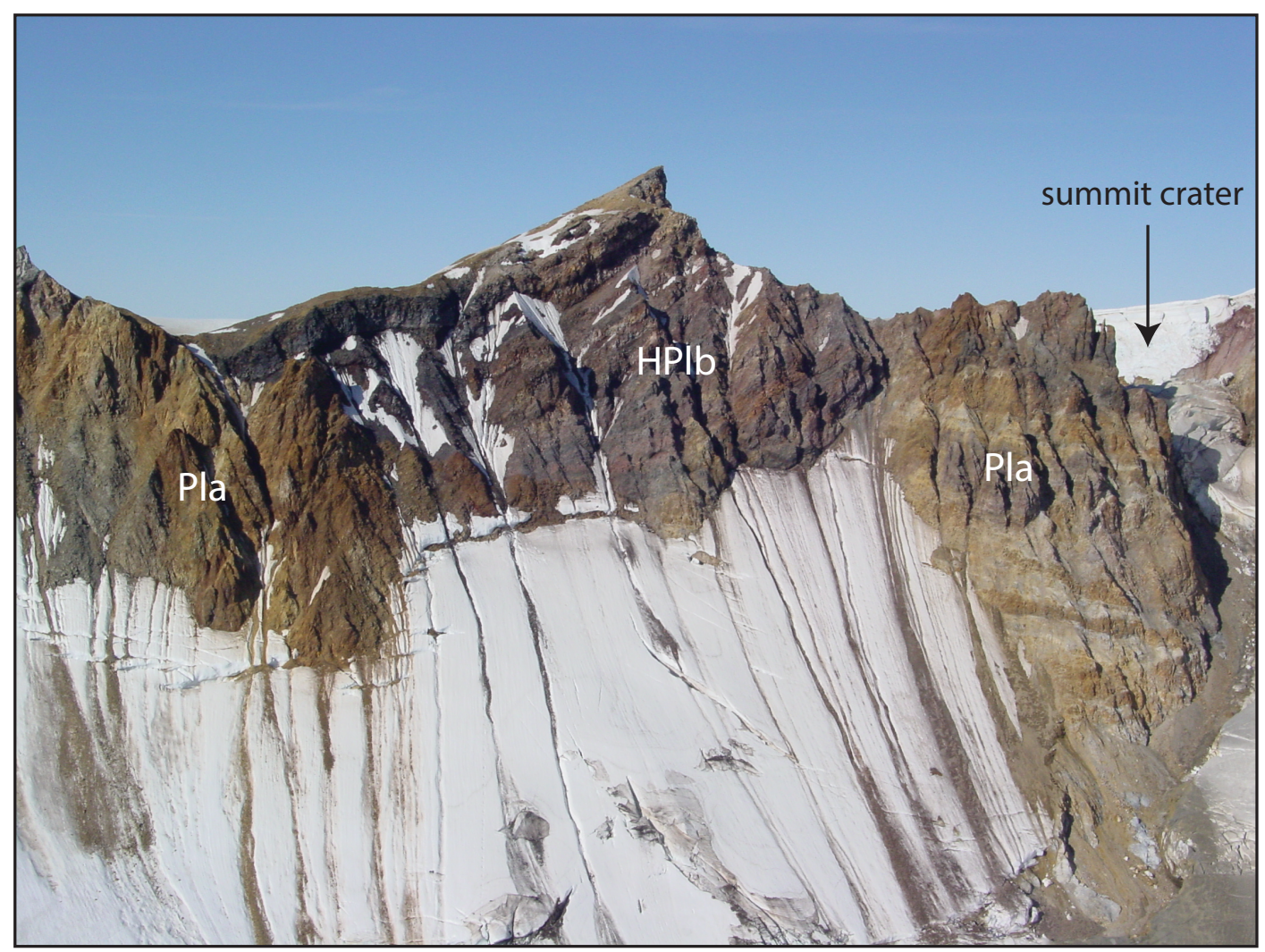

Figure 17. Hydrothermally altered lavas (units Pla and HPlb) in the summit region. Photo by G. McGimsey, August 21, 2005. AVO image database link: http://www.avo.alaska.edu/images/image. php?id=93111 


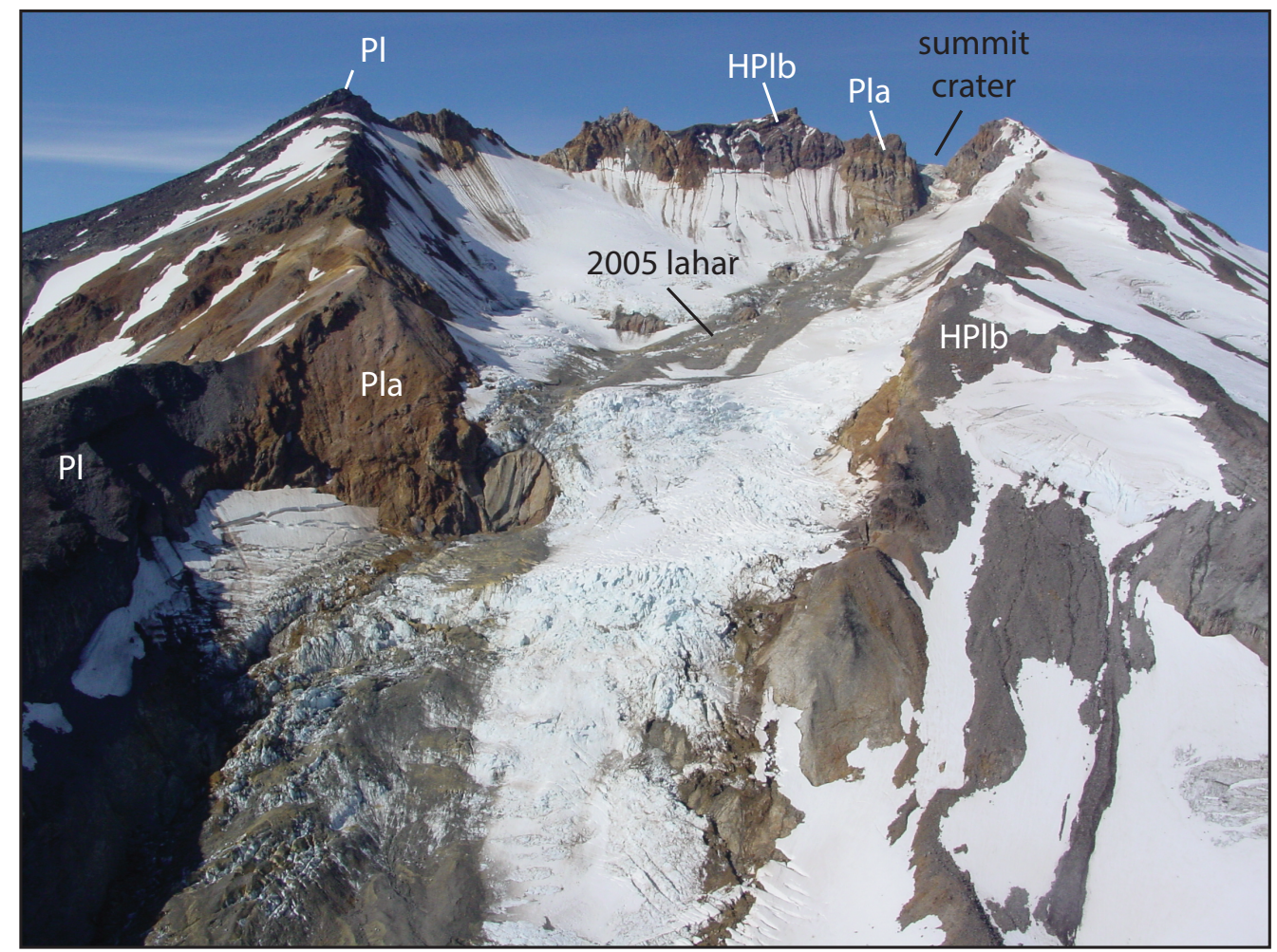

Figure 18. Pleistocene lava units in the summit area (units Pl, HPlb, Pla), including a 2005 non-eruptive lahar deposit on the south flank glacier. Photo by G. McGimsey, August 21, 2005. AVO image database link: http://www.avo.alaska.edu/images/image.php?id=93121

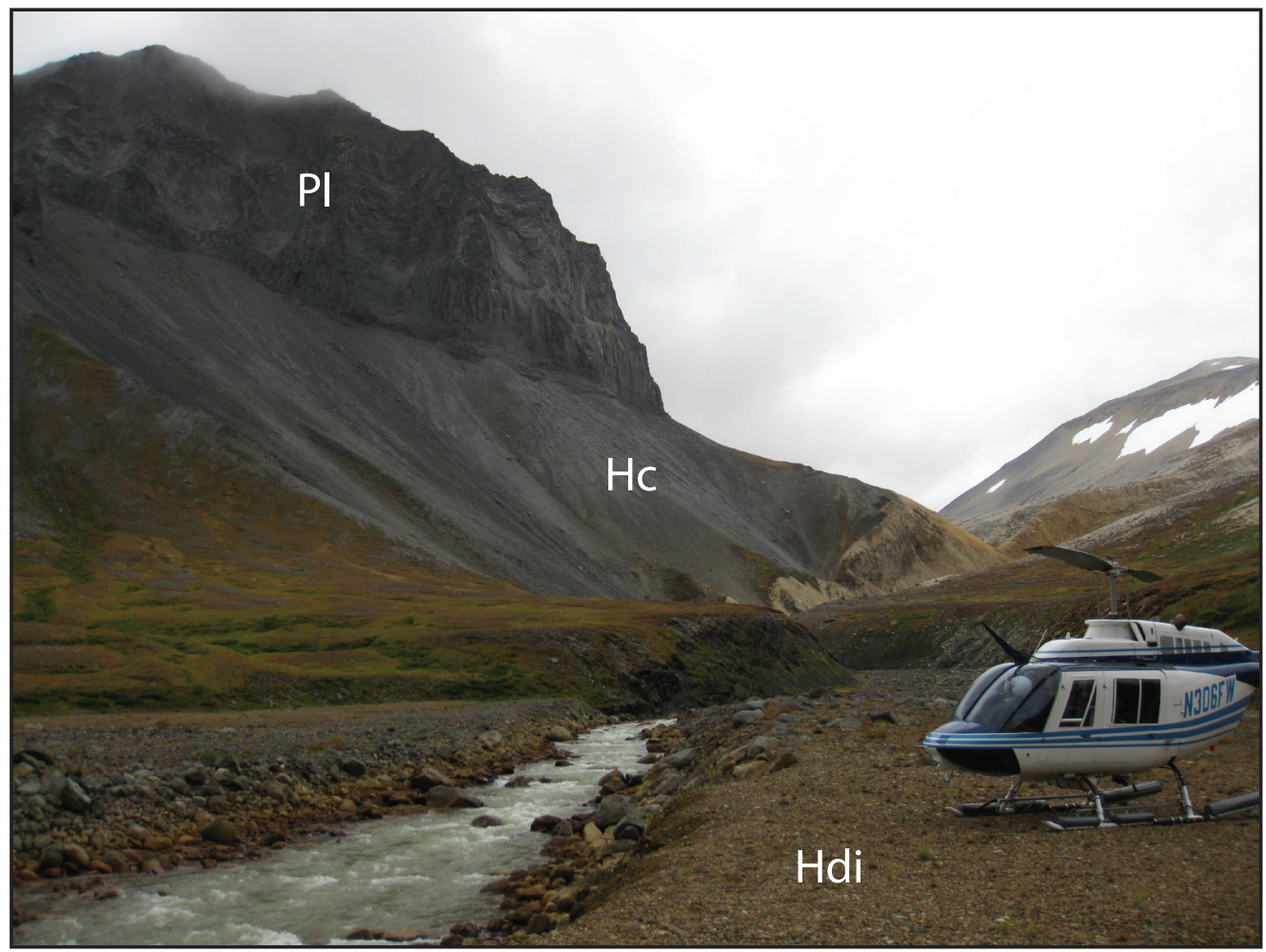

Figure 19. Holocene colluvium forms a sheet of talus at the base of Pleistocene ice-contact lava flows (unit PI) in upper Indecision Creek. The helicopter is parked on a terrace of debrisflow and lahar deposits (unit Hdi). Photo by J. Schaefer, September 27, 2012. AVO image database link: http://www.avo.alaska.edu/images/image.php?id=93131 


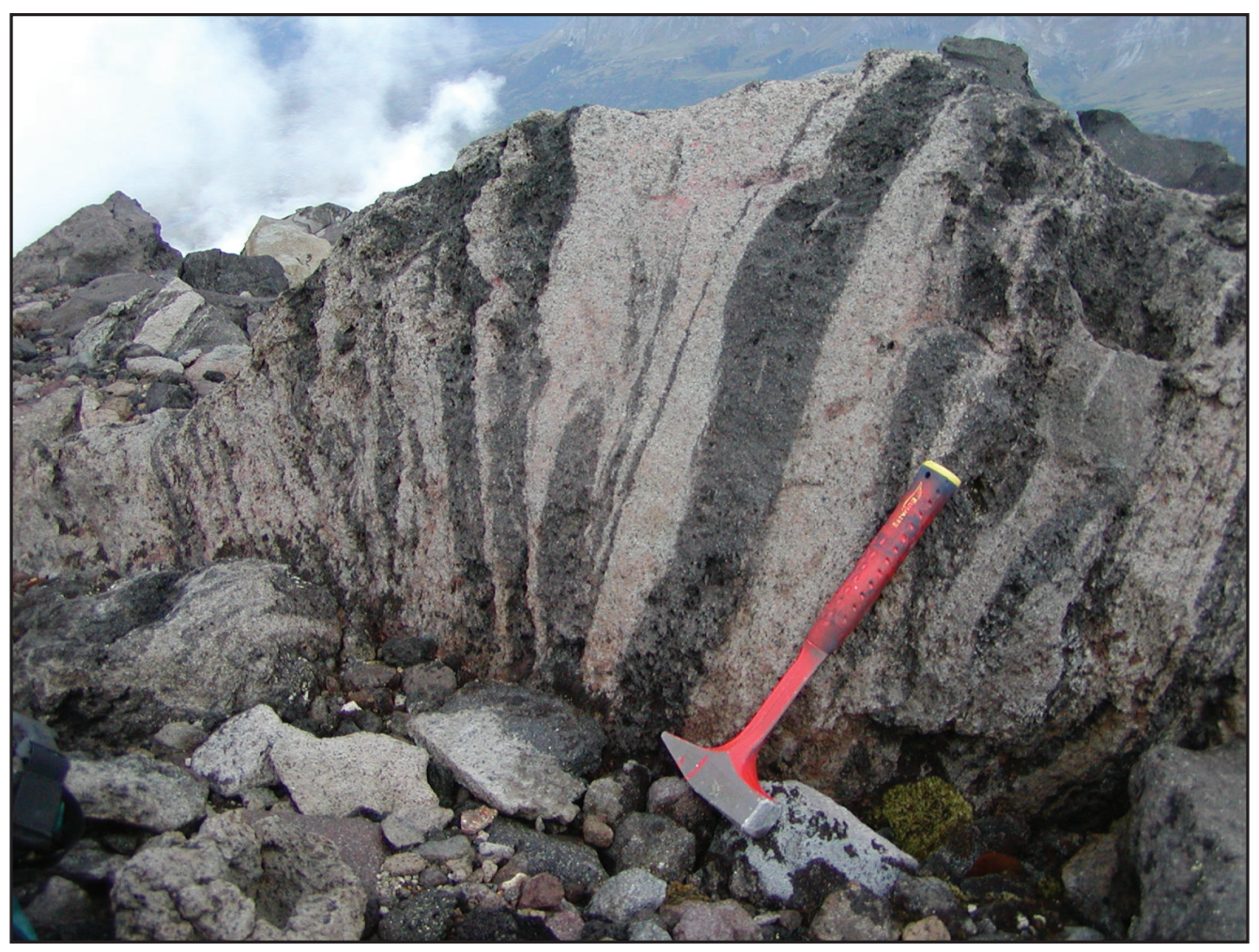

Figure 20. Banded andesite lava block from unit Pnb on the north flank. Photo by J. Schaefer, August 24, 2004. AVO image database link: http://www.avo.alaska.edu/images/image. php?id=1093 

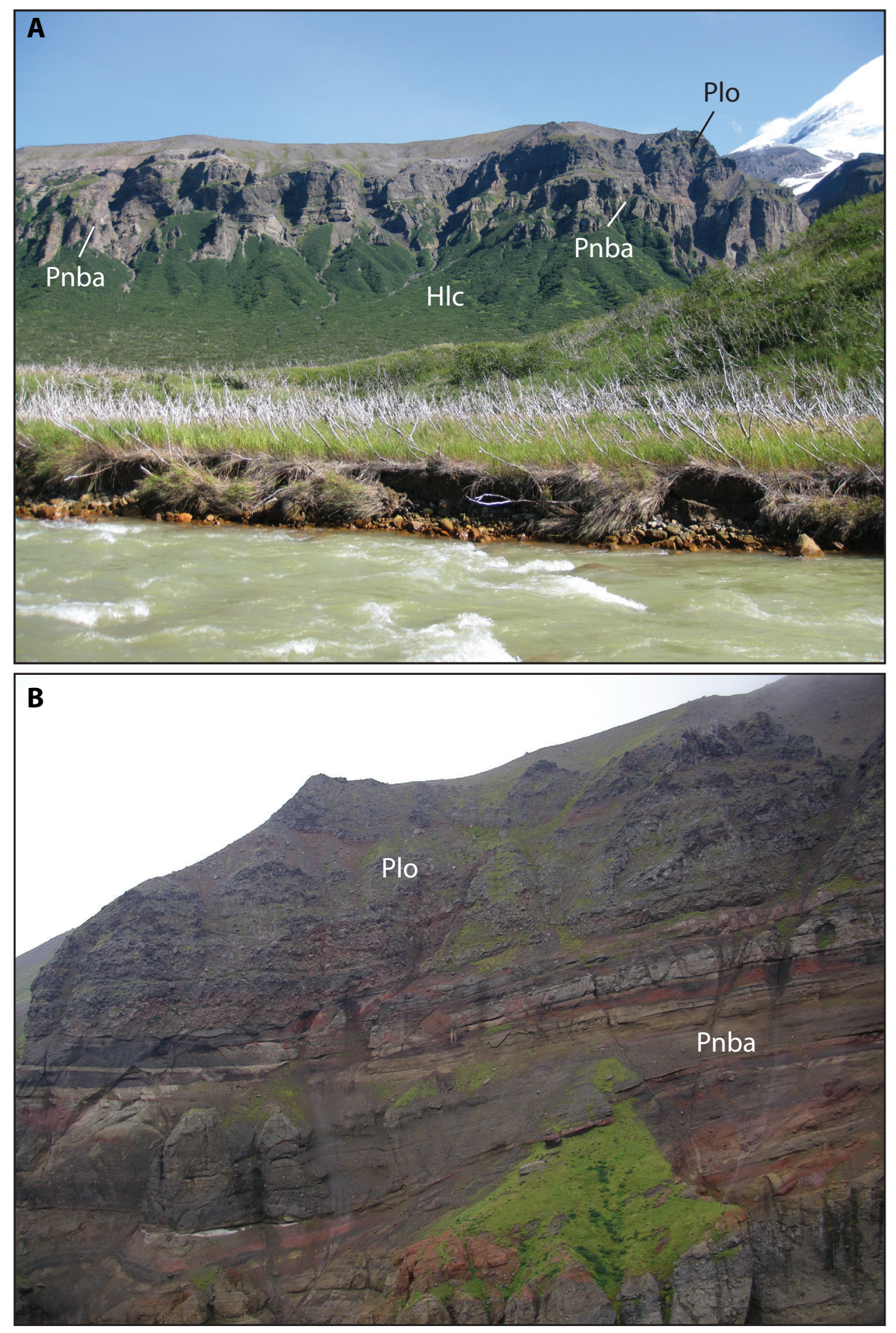

Figure 21. (A) Basaltic andesite lava flows (unit Plo) in the block-and-ash-flow deposits of the north flank (unit Pnba) exposed in the cliffs above lower Indecision Creek, with an apron of Holocene colluvium (unit HIc). The dead alders in the foreground along Indecision Creek are a result of acidic water draining into the creek from the summit crater lake (see Schaefer and others, 2008, for a description of the 2005 acid crater lake drainage event). Photo by J. Schaefer, August 26, 2009. AVO image database link: http://www.avo. alaska.edu/images/image.php?id=93091 (B) Closer view of cliff-forming Plo lava flows atop bedded, indurated, ash-flow deposits of unit Pnba. Photo by W. Scott, August 23, 2004. AVO image database link: http://www.avo.alaska.edu/images/image.php?id=965 


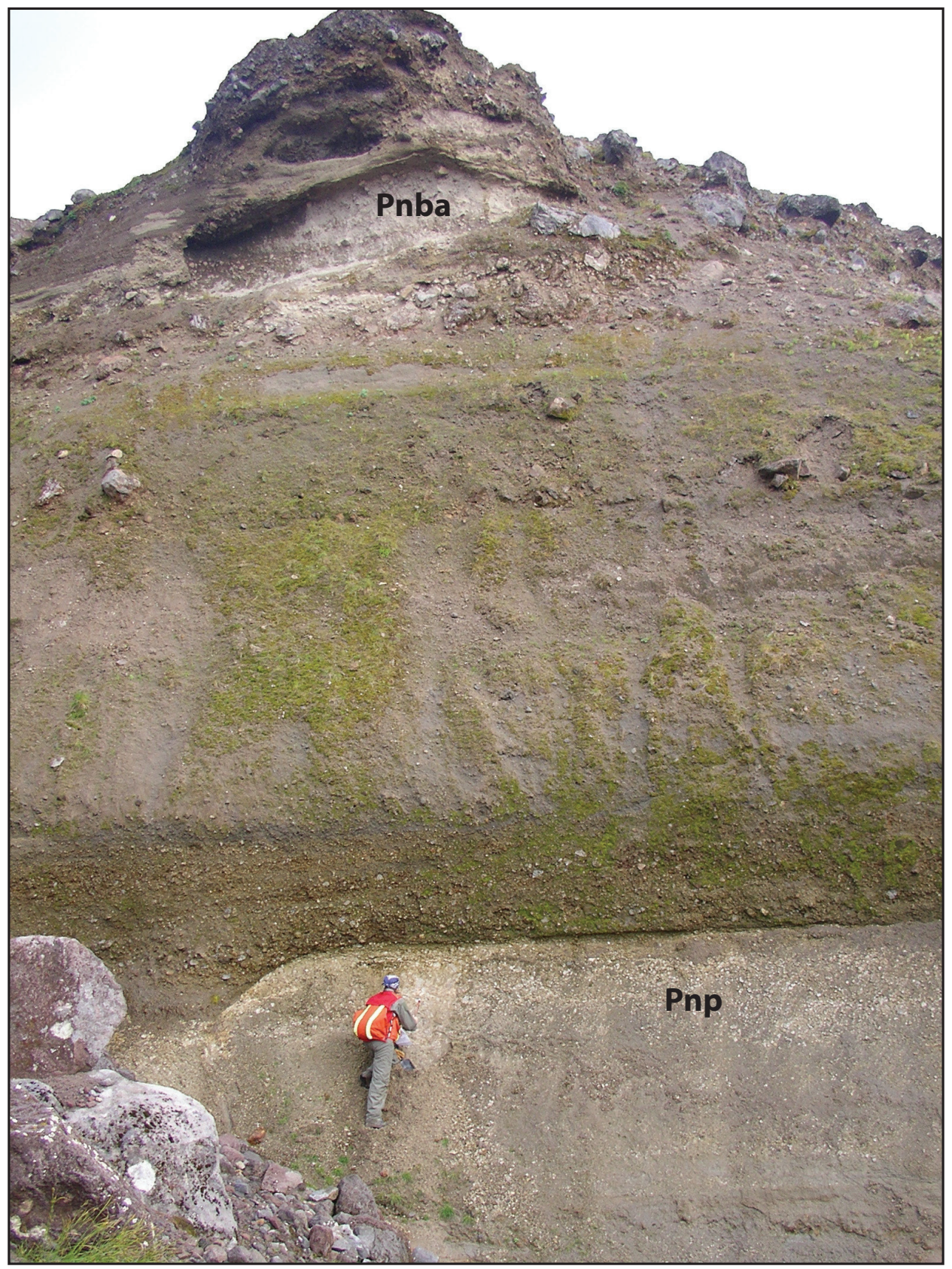

Figure 22. Pumice-rich fall deposit (unit Pnp) overlain by block-and-ash-flow deposits of unit Pnba on the northeast flank. Photo by W. Scott, August 23, 2004. AVO image database link: http://www.avo.alaska.edu/images/image. php?id=977

\section{ACKNOWLEDGMENTS}

Game McGimsey provided valuable field expertise during our excursion to Mount Chiginagak in 2005. His thoughtful review greatly improved the quality and content of the map and report. We thank Jessica Larsen for her helpful review and for providing expertise in geochemical data display. This work was made possible by cooperative agreements between the U.S. Geological Survey Volcano Hazards Program and the State of Alaska Division of Geological \& Geophysical Surveys, including grants G16AC00054 and G16AC00165. 


\section{REFERENCES}

Barclay, D.J., Wiles, G.C., Calkin, P.E., 2009, Holocene glacier fluctuations in Alaska, Quaternary Science Reviews 28, p. 2034-2048.

Bronk Ramsey, C., 2009, Bayesian analysis of radiocarbon dates, Radiocarbon v. 51, no. 1, p. 337-360.

Cameron, C.E., Snedigar, S.F., and Nye, C.J., 2014, Alaska Volcano Observatory Geochemical Database: Alaska Division of Geological \& Geophysical Surveys Digital Data Series 8, https://www.avo.alaska.edu/geochem/index. php, http://dx.doi.org/10.14509/29120

Coats, R.R., 1950, Volcanic activity in the Aleutian Arc: U.S. Geological Survey Bulletin 0974B, p. 35-49, 1 sheet, scale unknown.

Cohen, K.M., Finney, S.C., Gibbard, P.L., and Fan, J.-X., 2013, The ICS International Chronostratigraphic Chart, Episodes 36, p. 199204.

Detterman, R.L., Case, J.E., Wilson, F.H., and Yount, M.E., 1987a, Geologic map of the Ugashik, Bristol Bay, and western part of Karluk quadrangles, Alaska: U.S. Geological Survey Miscellaneous Investigations Series Map I-1685, unpaged, 1 plate, scale 1:250,000.

Detterman, R.L., Wilson, F.H., Yount, M.E., and Miller, T.P., 1987b, Quaternary geologic map of the Ugashik, Bristol Bay, and western part of Karluk quadrangles, Alaska: U.S. Geological Survey Miscellaneous Investigations Series Map I-1801, unpaged, 1 sheet, scale 1:250,000. http://www.dggs.dnr.state.ak.us/ pubs/pubs? reqtype $=$ citation $\& \mathrm{ID}=12928$

Granitto, Matthew, Schmidt, J., Shew, N.B., Gamble, B.M., and Labay, K.A., 2013, Alaska geochemical database, version 2.0 (AGDB2) including "best value" data compilations for rock, sediment, soil, mineral, and concentrate sample media: U.S. Geological Survey Data Series 759,29 p. http://pubs.er.usgs.gov/publication/ds 759

Johnson, D.M., Hooper, P.R., and Conrey, R.M., 1999, XRF analysis of rocks and minerals for major and trace elements on a single low dilution Li-tetraborate fused bead: Advances in
X-ray Analysis, v. 41, p. 843-867.

Kassel, C.M., 2009, Lacustrine evidence from Mother Goose Lake of Holocene geothermal activity at Mount Chiginagak, Alaska Peninsula: Flagstaff, AZ, Northern Arizona University, M.S. thesis, $138 \mathrm{p}$.

Kaufman, D.S., Young, N.E., Briner, J.P., Manley, W.F., 2011, Alaska Palaeo-Glacier Atlas (Version 2). In: Ehlers, J. and Gibbard, P.S. (eds), Quaternary Glaciations Extent and Chronology, Part IV: A Closer Look. Developments in Quaternary Science 15, Amsterdam, Elsevier, p. 427-445.

Knaack, C., Cornelius, S.B., and Hooper, P.R., 1994, Trace element analyses of rocks and minerals by ICP-MS: Pullman, WA, Washington State University, GeoAnalytical Lab Technical Notes, December 1994.

Layer, P.W., 2000, Argon-40/Argon-39 age of the El'gygytgyn impact event, Chukotka, Russia: Meteoritics and Planetary Science, v. 35, no. 3, p. 591-599. http://doi. org/10.1111/j.1945-5100.2000.tb01439.x

Macías, J.L., Arce, J.L., García-Palomo, A., Mora, J.C., Layer, P.W., and Espíndola, J.M., 2010, Late-Pleistocene flank collapse triggered by dome growth at Tacaná volcano, MéxicoGuatemala, and its relationship to the regional stress regime: Bulletin of Volcanology, v. 72, no. 33, p. 33-53. http://dx.doi.org/10.1007/ s00445-009-0303-9

Manley, William, and Kaufman, Darrell, 2002, Alaska PaleoGlacier Atlas-A Geospatial Compilation of Pleistocene Glacier Extents, http:// instaar.colorado.edu/QGISL/ak_paleoglacier_ atlas/

McGimsey, R.G., Neal, C.A., and Girina, Olga, 2003, 1998 volcanic activity in Alaska and Kamchatka-Summary of events and response of the Alaska Volcano Observatory: U.S. Geological Survey Open-File Report 03-0423, $35 \mathrm{p}$.

McGimsey, R.G., and Wallace, K.L., 1999, 1997 volcanic activity in Alaska and KamchatkaSummary of events and response of the Alaska Volcano Observatory: U.S. Geological Survey Open-File Report 99-0448, 42 p. 
Miller, T.P., McGimsey, R.G., Richter, D.H., Riehle, J.R., Nye, C.J., Yount, M.E., and Dumoulin, J.A., 1998, Catalog of historically active volcanoes of Alaska: U.S. Geological Survey Open-File Report, 98-582, 104 p.

Miyashiro, Akiho, 1974, Volcanic rock series in island arcs and active continental margins: American Journal of Science, v. 274, no. 4, p. 321355. http://dx.doi.org/10.2475/ajs.274.4.321

Motyka, R. J., Moorman, M. A., and Liss, S. A., 1981, Assessment of thermal springs sites, Aleutian arc, Atka Island to Becharof Lake-preliminary results and evaluation: Alaska Division of Geological \& Geophysical Surveys OpenFile Report AOF 0144, 173 p. http://doi. org/10.14509/64

Powers, H.A., 1958, Alaska Peninsula-Aleutian Islands, in Williams, H., ed., Landscapes of Alaska: Los Angeles, CA, University of California Press, p. 61-75.

Riehle, J.R., 1990, Chiginagak, in Wood, C.A., and Kienle, Jürgen., eds, Volcanoes of North America: Cambridge, Cambridge University Press, p. 61-62.

Riehle, J.R., Meyer, C.E., and Miyaoka, R.T., 1999, Data on Holocene tephra (volcanic ash) deposits in the Alaska Peninsula and lower Cook Inlet region of the Aleutian volcanic arc, Alaska: U.S. Geological Survey Open-File Report $99-0135,5 \mathrm{p}$.
Reimer, P.J., Bard E., Bayliss, A., Beck, J.W., Blackwell, P.G., Bronk, R.C., Buck, C.E., Cheng, H., Edwards, R.L., Friedrich, M., Grootes, P.M., Guilderson, T.P., Haflidason, H., Hajdas, I., Hatté, C., Heaton, T.J., Hoffmann, D.L., Hogg, A.G., Hughen, K.A., Kaiser, K.F., Kromer, B., Manning, S.W., Niu, M., Reimer, R.W., Richards, D.A., Scott, E.M., Southon, J.R., Staff, R.A., Turney, C.S.M., and van der Plicht, J., 2013, IntCal13 and Marine13 radiocarbon age calibration curves $0-50,000$ years cal BP, Radiocarbon, v. 55, no. 4, p. 1869-1887.

Schaefer, J.R., Scott, W.E., Evans, W.C., Jorgenson, J., McGimsey, R.G., and Wang, B., 2008, The 2005 catastrophic acid crater lake drainage, lahar, and acidic aerosol formation at Mount Chiginagak volcano, Alaska, USA_Field observations and preliminary water and vegetation chemistry results: Geochemistry Geophysics Geosystems, v. 9, no. 7, 29 p., Q07018. http:// dx.doi.org/10.1029/2007GC001900

Schaefer, J.R., Scott, W.E., Evans, W.C., Wang, Bronwen, and McGimsey, R.G., 2013, Summit crater lake observations, and the location, chemistry, and $\mathrm{pH}$ of water samples near Mount Chiginagak volcano, Alaska: 2004-2012: Alaska Division of Geological \& Geophysical Surveys Report of Investigation 2011-6 v. 2, 25 p. http://doi.org/10.14509/25602 